\title{
Energy Efficiency and the Role of Financial Development, Trade Openness and Technological Innovation: Exploring the Dynamic Linkages for Pakistan
}

Samia Nasreen ( $\nabla$ sami_lcu@yahoo.com )

Lahore College for Women University

\section{Sofia Anwar}

Government College University Faisalabad

\section{Research}

Keywords: Energy efficiency, Financial development, trade openness, technological innovation, Pakistan.

Posted Date: September 29th, 2020

DOI: https://doi.org/10.21203/rs.3.rs-84180/v1

License: (c) (1) This work is licensed under a Creative Commons Attribution 4.0 International License.

Read Full License 


\title{
Energy Efficiency and the Role of Financial Development, Trade Openness and Technological Innovation: Exploring the Dynamic Linkages for Pakistan
}

\author{
Samia Nasreen \\ Department of Economics \\ Lahore College for Women University \\ Lahore, Punjab (Pakistan) \\ sami_lcu@yahoo.com \\ Sofia Anwar \\ Department of Economics \\ Government College University Faisalabad \\ Faisalabad, Punjab (Pakistan) \\ Sofia_eco@gcuf.edu.pk
}

\begin{abstract}
The study explores the dynamic linkages among financial development, trade openness, technological innovation and energy efficiency in Pakistan utilizing cointegration tests, Directed Acyclic Graphs (DAG) and Structural Vector Autoregression (SVAR) model for the period 19802017. The results of Johansen cointegration show that variables ae cointegrated. The robustness of cointegration relationship is confirmed by applying Gregory-Hansen structural break cointegration. The empirical findings imply that financial development and technological innovation positively and significantly stimulate energy efficiency while trade openness and economic growth negatively and significantly impact on energy efficiency in long-run. The DAG results explain the evidence of causality from financial development, trade openness, technological innovation and economic growth to energy efficiency. The results of forecast error variance decomposition from SVAR model describe that technological innovation has greater impact on energy efficiency in short-term but its impact gradually decreases with the extension of forecast period. On contrary, the promotion effect of financial development and trade openness on energy efficiency increase gradually over time and become highest in long-run. This finding underlines the relevance of technological innovation and trade openness to policy makers in order to achieve energy efficiency in Pakistan.
\end{abstract}

Keywords: Energy efficiency; Financial development; trade openness; technological innovation; Pakistan. 


\section{1-Introduction}

Energy is an essential input in production and its availability and utilization is indispensable for socio-economic uplift and technological advancement of a nation. Nowadays, world economies main focus is to achieve energy efficiency in national output due to the importance of energy in everyday life and finite nature of primary energy resources. Efficient use of energy at national level can reduce energy imports, thereby reducing pressure on foreign reserves as well as ensuring the availability of energy scarce resources for future generation. At firm level, energy efficiency is indispensable for reducing operating cost and enhance profitability. Society as a whole can benefits from the increased energy efficiency because it is a key policy option to mitigate the adverse impact of environment (Rajbhandari and Zhang, 2017). In this regard, several ecological policy options have been formulated that major focus is to increase energy efficiency via technological advancement. Technological innovation has the tendency to generate solutions of enormous energy use through the discovery of energy efficient techniques that may have the potential to reduce energy intensities at industrial and household level (Saudi et al. 2019).

Financial development stimulates and promotes the financial activities in a country such as banking activity, stock market activity and foreign capital and investment flows, which increase economic efficiency and expand the level of output (Sadorsky, 2010 and 2011). Trade is an essential factor in the progress of nations. Trade enables developing economies to import modern technologies that are helpful in reducing energy consumption in production (Nasreen and Anwar, 2014). Trade is only possible with the sufficient supply of energy because it is the key input in production and transportation of goods and services demand energy to fuel vehicles. No doubt, energy is an indispensable factor in the expansion of exports or imports, thereby any policy aims 
to reduce energy consumption such as energy saving polices may adversely impact the flow of international trade and hence reduces the advantage of trade liberalization (Shahbaz et al. 2014).

The main objective of current research is to explore the dynamic interaction among energy efficiency, financial development, trade openness and technological innovation in Pakistan. Our study is relevant given that the findings of current literature investigating the association between energy usage and macroeconomic variables are in general mixed and do not reach any definite conclusion (e.g. Sadorsky, 2011; Tang and Tan, 2013; Chang, 2015; Najarzadeh et al. 2015; Irandoust, 2016; Rajneesh, 2018; Gomez and Rodriguez, 2019; Saudi et al. 2019). Using timeseries framework, this study proposes a methodological approach that comprises DAG technique and the estimation of SVAR in multivariate framework. Such analysis would be of key importance to policy makers of Pakistan to formulate future energy policies regarding the usage of energy which is one of the most valuable resources for economy.

Therefore, the study adds to the earlier literature in four ways. (i) Many studies examine the causation between energy consumption and financial development (Boutabba (2014; Mahalik and Mallick, 2014; Siddique and Majeed, 2015; Rafindadi and Ozturk, 2017), energy consumption and trade openness (Nasreen and Anwar, 2014; Shahbaz et al., 2014; Akhtar et al. 2016; Koengkan, 2018), energy consumption and technological innovation (Irandoust, 2016; Khan et al. 2016; Jin et al. 2018; Akinwale, 2018) but the results have been mixed and ambiguous. Nonetheless, no significant contributions have been made in examining dynamic association among energy efficiency, trade openness, financial development and technological advancements in developing economies. In the present research, we explore the dynamic causation among energy efficiency, financial development, trade openness and technological innovation in Pakistan. (ii) We apply DAG to study the contemporaneous causal flows among energy efficiency and selected 
macroeconomic variables in a multivariate framework. (iii) We investigate dynamic association among macroeconomic variables under consideration by using SVAR approach. (iv) Our study is unique in the sense that we could not find any previous research on energy that have applied abovementioned methodological approaches in Pakistan.

The organization of the paper is as follows. energy outlook in Pakistan is presented in Section 2, review of literature in Section 3, empirical methodology in Section 4, empirical results in Section 5, conclusion and policy implications in Section 6.

\section{2-Energy Outlook in Pakistan}

Pakistan is developing country and central position of energy in the economy as a whole is paramount. Fig. 1 shows that periods of high growth rate of GDP are coincide with high growth rate of energy consumption and periods of lower GDP growth depicts lower energy consumption.

Fig.1: Trends in Energy Consumption and Economic Growth

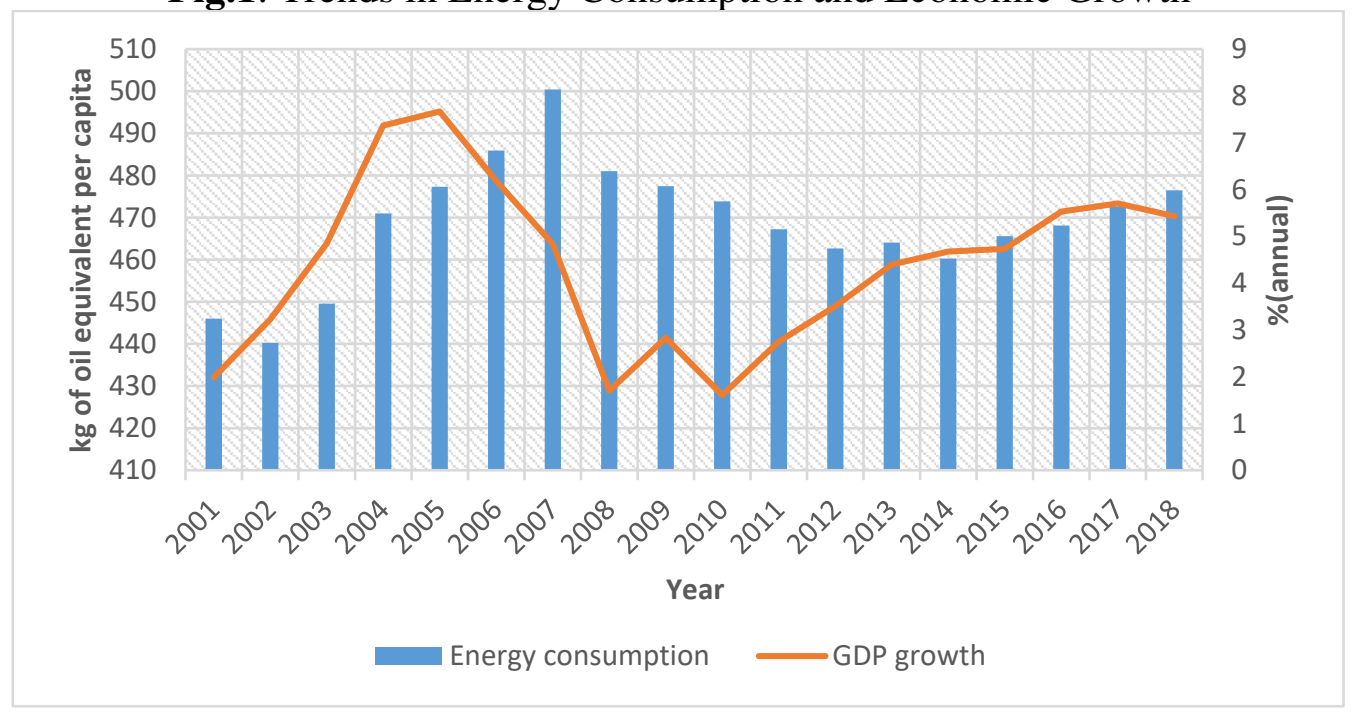

Sources: WDI, World Bank 
Pakistan is heavily dependent on oil and gas to fulfill their energy demand. However, energy demand far exceeds its domestic supply which is fulfilled through imported crude oil and petroleum products. Oil and gas, primary energy mix, are contributing almost $80 \%$ of energy supplies during 2015 while share of coal and nuclear is approximately $7 \%$ and $2 \%$ respectively (see Fig.2). On average, the growth rate of primary energy supply is estimated as $1.4 \%$ for the last five years.

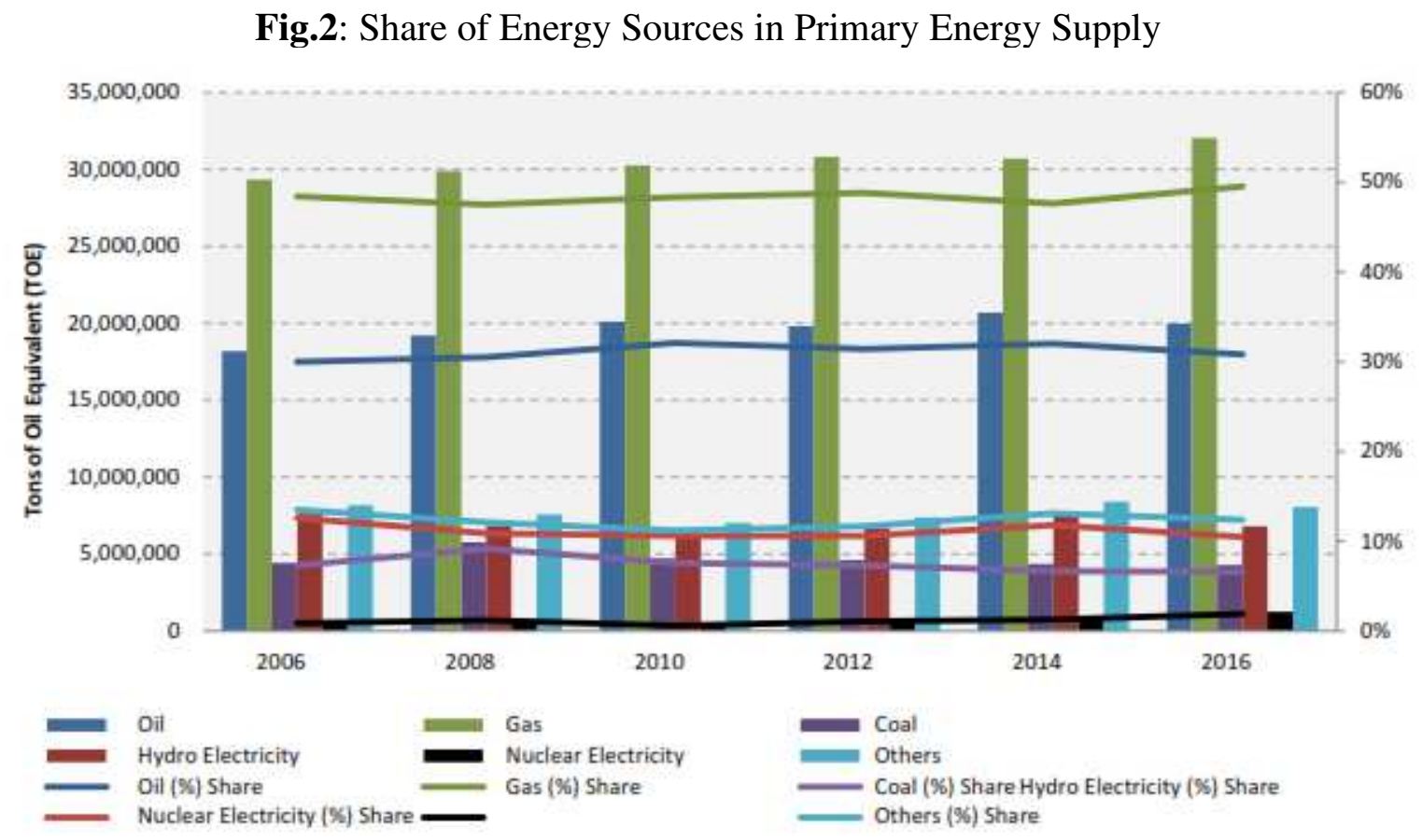

Source: Hydrocarbon Development Institute of Pakistan

The final energy consumption (from both primary and secondary sources) was 50.02Mn TOE during 2016 as compared to $48.74 \mathrm{Mn}$ TOE in 2015, total increase in $3.1 \%$. However, the average growth rate of final energy consumption remained $2.4 \%$ during the last five years. Statistics portrayed in Fig. 3 show that the share of oil and gas is largest in total energy consumption. 
Fig.3: Contribution of Energy Sources in Final Energy Consumption

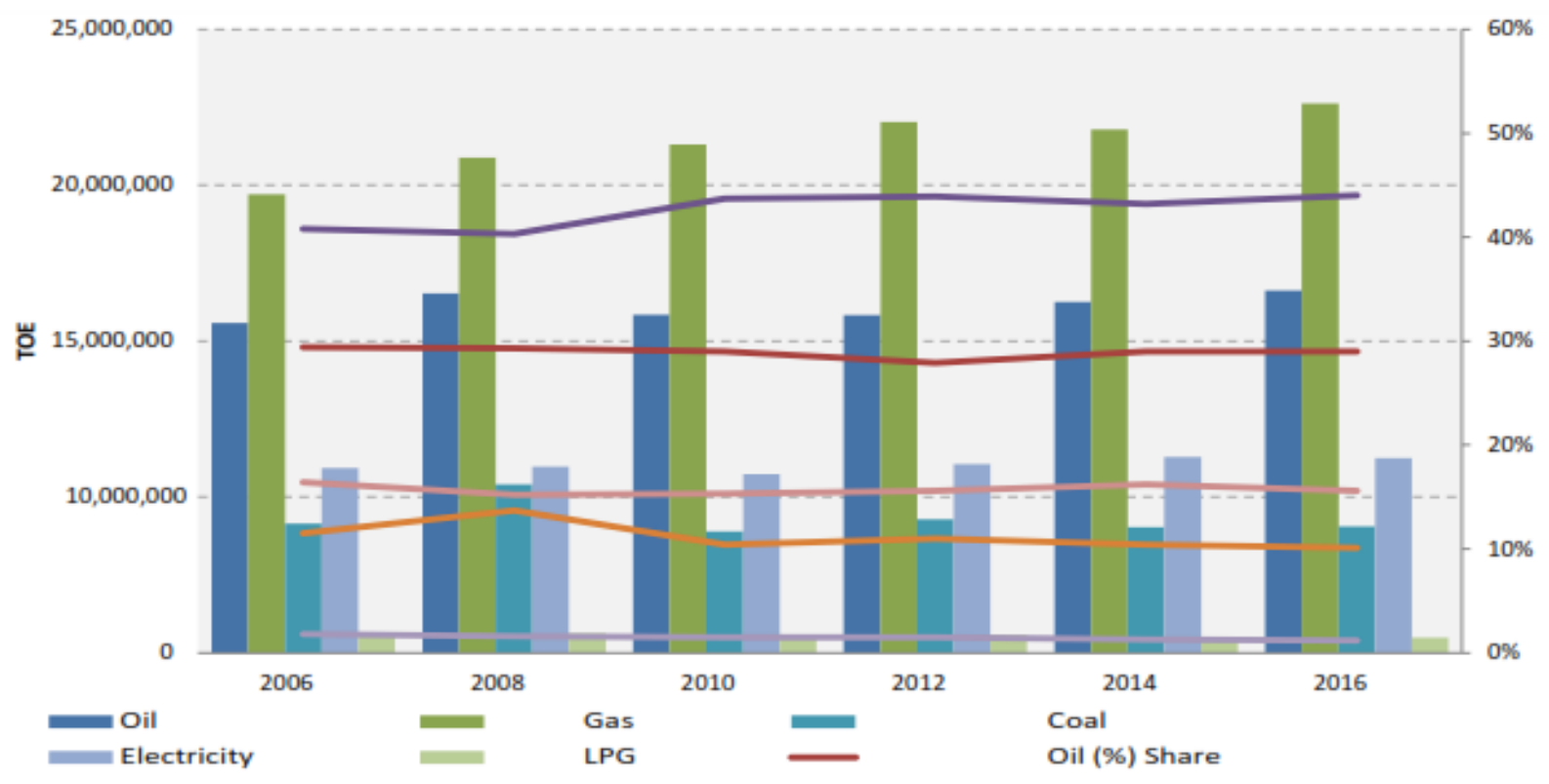

Source: Hydrocarbon Development Institute of Pakistan

Sectoral distribution of energy consumption is presented in Fig.4. Industry is the largest energy intensive sector followed by transport and household, consuming 38\%, 34\% and $20 \%$ of total energy supply respectively. The consumption of energy in agriculture sector is $2 \%$ and commercial sector is $4 \%$. The consumption mix of energy has changed over time in industry and services sector, electricity consumption increased and gas consumption decreased. In addition, the consumption of oil has been increased in both these sectors.

Energy efficiency of Pakistan's industries is among the lowest in the world and consuming enormous energy with as annual increase of $5 \%$ to $6 \%$ of electricity demand. Pakistan had the same level of energy efficiency as India in 1980. However, the improvement in energy efficiency in India (1.9\% per annum) and Sri Lanka (1.5\% per annum) is much faster than from Pakistan 
(1.3\% per annum). Now, Pakistan is $15 \%$ less energy efficient than India. However, overall, the value of energy efficiency measured by energy intensity has been increased in Pakistan with the passage of time, 5.63\% in 1999 to $4.27 \%$ in 2017 (see Fig.5).

Fig.4: Distribution of Energy by Sector

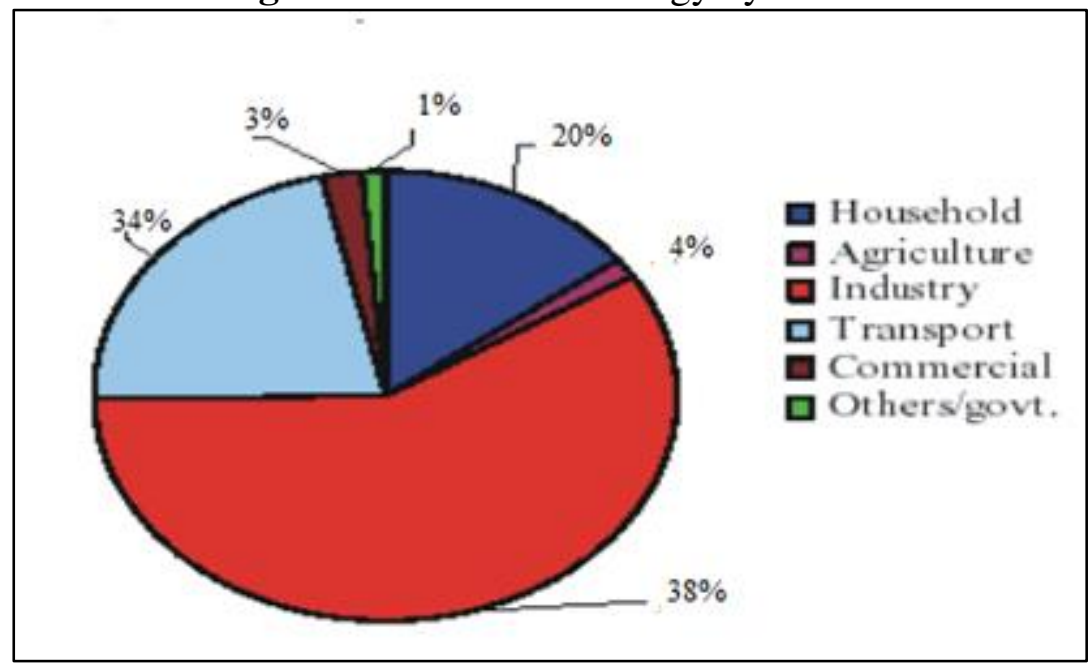

Source: State Bank of Pakistan, Quarterly Report for the Year 2017.

Fig. 5: Trends in Energy Efficiency

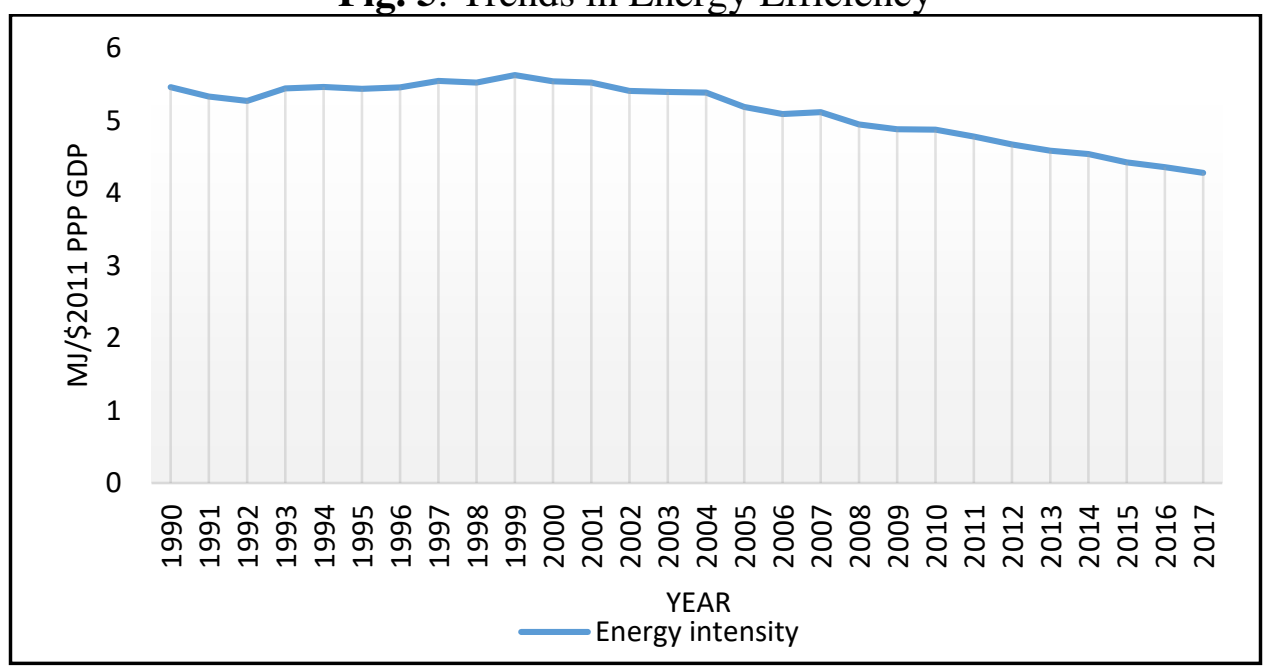

Source: WDI, World Bank 
Pakistan is one of the most energy inefficient countries and conversion rate to GDP. Despite this, Pakistan has substantial potential for energy saving from energy conservation and energy efficiency measures. 11 million TOE of energy saving can best be achieved by appropriate pricing and product subsidization policies, which enforce consumers to make appropriate changes in their life style and the usage of equipment. Furthermore, government intervention through strict rules and legislation is required to make a serious impact on the inefficient usage of energy.

\section{3-Review of Literature}

The findings of the current literature investigating the association between financial development, and energy consumption are mixed and in general are quite ambiguous which may be due to the use of different models that are based on different assumptions and the analysis of different time scales. For instance, Sadrosky (2010); Sadorsky (2011); Boutabba (2014); Chang (2015); Bekhet et al. (2017); Mukhtarov et al. (2018) noted positive association between development of financial market and energy consumption, Shahbaz (2015); Rafindadi and Ozturk (2017); Gomez and Rodriguez (2019) noted feedback relationship between both variables. However, Siddique and Majeed (2015); Pan et al. (2019) disclosed insignificant relationship between financial sector development and energy demand.

The connection between trade and energy is extensively investigated in empirical literature. For instance, Shahbaz et al. (2013 a) noted feedback connectedness that is energy is necessary for increasing the flow of international trade and likewise, international trade is the major factor for increasing energy demand in Indonesia. Nasreen and Anwar (2014) observed similar finding for Asian countries, Kyophilavong et al. (2015) for Thailand and Sun et al. (2019) for Belt and Road regions. Using the data of 91 countries, Shahbaz et al. (2014) highlight the unidirectional connectedness from energy consumption to trade openness. Halicioglu (2011) and Ghani (2012) 
reported insignificant impact of trade liberalization on energy demand in developing countries. Rafiq et al. (2016) noted inverse correlation between trade and energy demand. Cole (2006) argued that the share of energy intensive products in country's total exports or imports signify the impact of trade on energy consumption. Jena and Grote (2008) demonstrated that liberalization policies enhances energy demand through technique effect, scale effect and composite effect.

A considerable attention has been shown in empirical literature on the interaction between technological advancements and energy efficiency. Most of the previous studies concluded that energy efficiency depends upon technological innovation (see e.g. Irandoust, 2016; Wei et al. 2016; Jin et al. 2018). In the case of Malaysia, Sohag et al. (2015) concluded that technological progress has direct impact on energy intensity and correspondingly energy efficiency at every stage of production level. Jin and Zhang (2014) noted that technological progress is inversely related to fossil fuel consumption. Fei and Rasiah (2014) found insignificant impact of technological progress on electricity consumption. Tang and Tan (2013) suggested that technological advancements have negative impact on electricity demand and technological progress Granger cause electricity demand in Malaysia. Irandoust (2016) reported the causality from technological innovation to renewable energy. Khan et al. (2016) empirical findings explained that technological innovation increased the demand for coal and natural gas while reduced the demand for oil in Pakistan.

In a recent study, Saudi et al. (2019) found that technological innovation is a strong determinant of energy inefficiency in Indonesia. Farhani and Solarin (2017) demonstrated the negative impact of capital market development and real GDP on energy demand, while positive impact of trade and capital on energy usage in USA. Pan et al. (2017) concluded that the role of environmental regulation is important in reducing energy intensity through technological progress in China. In 
another study, Pan et al. (2019) estimated results explain that developed financial markets, trade openness policies, economic growth strategies and rules for technological advancements determined the demand energy intensity in Bangladesh. Using the provincial level data from China, Jin et al. (2018) found the positive effect of technological progress on the usage of energy. On contrary, Akinwale (2018) found that technological progress and energy demand are inversely related and technological progress Granger cause energy demand in Saudi Arabia.

It is clear from the above-mentioned empirical studies that evidence on the association between energy usage, financial development, international trade and technological innovation are mixed and demand for further analysis. In this paper, we look at the above associations and try to contribute to the discussion of causation. For further detail, one can see the summary of literature presented in Table 1.

\section{4-Methodology}

\section{1-Theoretical Framework}

Energy play a key role in national output. The upward trend in energy usage especially nonrenewable energy causing a huge pressure on finite resources of energy. Thus, it has become an important area of research to explore the factors responsible for the huge usage of energy. In empirical literature, energy intensity is generally used to measure the level of energy efficiency in a country. Energy intensity mean consumption of energy per unit of output and its low value indicate the efficient use of energy resources in production (Pen et al., 2019). There are number of macroeconomic variables such as output growth, trade openness, technological innovation etc. that can influence energy efficiency directly or indirectly. 
Table 1: Summary of Empirical Literature

\begin{tabular}{|c|c|c|c|c|c|c|c|c|c|c|}
\hline \multirow[t]{3}{*}{ Authors } & \multirow[t]{3}{*}{ Sample countries } & \multirow{3}{*}{$\begin{array}{l}\text { Period of } \\
\text { study }\end{array}$} & \multirow{3}{*}{$\begin{array}{l}\text { Modelling } \\
\text { approach }\end{array}$} & \multicolumn{2}{|c|}{ Long run estimates } & \multicolumn{5}{|c|}{ Direction of causality } \\
\hline & & & & \multirow[t]{2}{*}{ Positive } & \multirow[t]{2}{*}{ Negative } & \multicolumn{2}{|c|}{ Unidirectional } & \multirow{2}{*}{$\begin{array}{l}\text { Bidirectional } \\
\text { FD } \Leftrightarrow \mathrm{E}\end{array}$} & \multirow{2}{*}{$\begin{array}{l}\text { No } \\
\mathrm{FD}_{\neq} \mathrm{E} \\
\end{array}$} & \multirow{2}{*}{$\begin{array}{l}\text { Not } \\
\text { studied }\end{array}$} \\
\hline & & & & & & $\mathrm{FD} \Rightarrow \mathrm{E}$ & $\mathrm{E} \Leftrightarrow \mathrm{FD}$ & & & \\
\hline \multicolumn{11}{|c|}{ Financial development and energy consumption } \\
\hline Sadrosky (2010) & $\begin{array}{l}22 \text { emerging } \\
\text { countries }\end{array}$ & $1960-2006$ & GMM & $\checkmark$ & & & & & & $\checkmark$ \\
\hline Sadorsky (2011) & \begin{tabular}{|l|}
9 Central and \\
Eastern European \\
frontier \\
economies \\
\end{tabular} & $1966-2006$ & GMM & $\checkmark$ & & & & & & $\checkmark$ \\
\hline Boutabba (2014) & India & $1970-2008$ & $\begin{array}{l}\text { ARDL, } \\
\text { VECM }\end{array}$ & $\checkmark$ & & $\checkmark$ & & & & \\
\hline Chang (2015) & 53 countries & $1999-2008$ & $\begin{array}{l}\text { Panel } \\
\text { threshold } \\
\text { regression }\end{array}$ & $\checkmark$ & & & & & & $\checkmark$ \\
\hline $\begin{array}{l}\text { Rashid and } \\
\text { Yousaf (2015) }\end{array}$ & \begin{tabular}{|l|} 
India and \\
Pakistan \\
\end{tabular} & $1980-2011$ & GMM & $\checkmark$ & & & & & & $\checkmark$ \\
\hline $\begin{array}{l}\text { Mahalik et al. } \\
\text { (2017) }\end{array}$ & Saudi Arabia & $1971-2011$ & ARDL, IAP & $\checkmark$ & & $\checkmark$ & & & & \\
\hline $\begin{array}{l}\text { Mahalik and } \\
\text { Mallick (2014) }\end{array}$ & India & 1971-2009 & ARDL & & $\checkmark$ & & & & & $\checkmark$ \\
\hline $\begin{array}{l}\text { Shahbaz et al. } \\
(2016)\end{array}$ & India & 1971-2012 & ARDL & & $\checkmark$ & & & & & $\checkmark$ \\
\hline $\begin{array}{l}\text { Siddique and } \\
\text { Majeed (2015) }\end{array}$ & \begin{tabular}{|l|}
$\begin{array}{l}\text { South Asian } \\
\text { countries }\end{array}$ \\
\end{tabular} & $1980-2010$ & $\begin{array}{l}\text { PMG, Panel } \\
\text { VECM }\end{array}$ & $\checkmark$ & & & & & $\checkmark$ & \\
\hline $\begin{array}{l}\text { Rafindadi and } \\
\text { Ozturk (2017) }\end{array}$ & South Africa & $1970-2011$ & $\begin{array}{l}\text { ARDL, } \\
\text { VECM }\end{array}$ & $\checkmark$ & & & & $\checkmark$ & & \\
\hline $\begin{array}{l}\text { Paramati et al. } \\
\text { (2017) }\end{array}$ & \begin{tabular}{|l|}
20 emerging \\
market \\
economies
\end{tabular} & $1991-2012$ & $\begin{array}{l}\text { Cointegration, } \\
\text { DH panel } \\
\text { causality test }\end{array}$ & $\checkmark$ & & $\checkmark$ & & & & \\
\hline $\begin{array}{l}\text { Mukhtarov et al. } \\
\text { (2018) }\end{array}$ & Azerbaijan & $1992-2015$ & Cointegration & $\checkmark$ & & & & & & $\checkmark$ \\
\hline
\end{tabular}




\begin{tabular}{|c|c|c|c|c|c|c|c|c|c|c|}
\hline $\begin{array}{l}\text { Gomez and } \\
\text { Rodriguez (2019) }\end{array}$ & \begin{tabular}{|l|} 
NAFTA \\
countries
\end{tabular} & $1971-2015$ & $\begin{array}{l}\text { Cointegration, } \\
\text { Panel Granger } \\
\text { causality test }\end{array}$ & & $\checkmark$ & & & $\checkmark$ & & \\
\hline Pan et al. (2019) & Bangladesh & $1976-2014$ & DAG,SVAR & $\checkmark$ & & $\checkmark$ & & & & \\
\hline \multicolumn{6}{|c|}{ Trade openness and energy consumption } & $\operatorname{Tr} \Rightarrow \mathrm{E}$ & $\mathrm{E} \Rightarrow \mathrm{Tr}$ & $\operatorname{Tr} \Leftrightarrow \mathrm{E}$ & $\operatorname{Tr} \neq \mathrm{E}$ & \\
\hline Ghani (2012) & \begin{tabular}{|l|}
$\begin{array}{l}54 \text { developing } \\
\text { countries }\end{array}$ \\
\end{tabular} & 1970-1999 & Fixed effect & & $\checkmark$ & & & & & $\checkmark$ \\
\hline Katircioglu (2013) & Singapore & 1980-1999 & VECM & $\checkmark$ & & & $\checkmark$ & & & \\
\hline $\begin{array}{l}\text { Shahbaz et al. } \\
\text { (2014) }\end{array}$ & 91 countries & $1980-2010$ & $\begin{array}{l}\text { Cointegration, } \\
\text { HV causality } \\
\text { test }\end{array}$ & $\checkmark$ & & & & $\checkmark$ & & \\
\hline $\begin{array}{l}\text { Nasreen and } \\
\text { Anwar (2014) }\end{array}$ & $\begin{array}{l}15 \text { Asian } \\
\text { countries }\end{array}$ & $1980-2011$ & $\begin{array}{l}\text { Cointegration, } \\
\text { Panel Granger } \\
\text { causality test }\end{array}$ & $\checkmark$ & & & & $\checkmark$ & & \\
\hline $\begin{array}{l}\text { Akhtar et al. } \\
(2016)\end{array}$ & $\begin{array}{l}\text { 4 South Asian } \\
\text { countries }\end{array}$ & $1974-2013$ & $\begin{array}{l}\text { Cointegration, } \\
\text { DH panel } \\
\text { causality test }\end{array}$ & & $\checkmark$ & & $\checkmark$ & & & \\
\hline $\begin{array}{l}\text { Najarzadeh et al. } \\
(2015)\end{array}$ & $\begin{array}{l}10 \text { OPEC } \\
\text { countries }\end{array}$ & $1985-2009$ & $\begin{array}{l}\text { Cointegration, } \\
\text { Panel Granger } \\
\text { causality test }\end{array}$ & $\checkmark$ & & & & $\checkmark$ & & \\
\hline Arif et al. (2017) & 4 Asian countries & 1972-2011 & $\begin{array}{l}\text { Cointegration, } \\
\text { PMG }\end{array}$ & $\checkmark$ & & & & $\checkmark$ & & \\
\hline Koengkan (2018) & \begin{tabular}{|l|}
4 Andean \\
community \\
countries
\end{tabular} & 1971-2014 & GMM & $\checkmark$ & & & & & & $\checkmark$ \\
\hline Jibrilla (2018) & Nigeria & $1981-2015$ & ARDL & & $\checkmark$ & & & & & $\checkmark$ \\
\hline Rajneesh (2018) & India & 1973-2013 & ARDL & & $\checkmark$ & & & & & $\checkmark$ \\
\hline Lau et al. (2018) & Malaysia & $1980-2015$ & $\begin{array}{l}\text { ARDL, } \\
\text { VECM }\end{array}$ & & $\checkmark$ & & & & $\checkmark$ & \\
\hline \multicolumn{6}{|c|}{ Technological innovation and energy consumption } & $\mathrm{TI} \Rightarrow \mathrm{E}$ & $\mathrm{E} \Rightarrow \mathrm{TI}$ & $\mathrm{TI} \Leftrightarrow \mathrm{E}$ & $\mathrm{TI} \neq \mathrm{E}$ & \\
\hline $\begin{array}{l}\text { Du and Yan } \\
(2009)\end{array}$ & China & 2007 & $\begin{array}{l}\text { Regression } \\
\text { analysis }\end{array}$ & & $\checkmark$ & & & & & $\checkmark$ \\
\hline $\begin{array}{l}\text { Tang and Tan } \\
\text { (2013) }\end{array}$ & Malaysia & 1970-2009 & $\begin{array}{l}\text { ARDL, } \\
\text { Granger } \\
\text { causality test }\end{array}$ & & $\checkmark$ & $\checkmark$ & & & & \\
\hline Sohag et al. & Malaysia & $1985-2012$ & ARDL & & $\checkmark$ & & & & & \\
\hline
\end{tabular}




\begin{tabular}{|l|l|l|l|l|l|l|l|l|l|}
\hline $\begin{array}{l}\text { (2015) } \\
\text { Irandoust } \\
\text { (2016) }\end{array}$ & Nordic & $1975-2012$ & $\begin{array}{l}\text { Granger } \\
\text { causality test }\end{array}$ & $\checkmark$ & & & \\
\hline Khan et al. (2016) & Pakistan & $1971-2013$ & $\begin{array}{l}\text { ARDL, } \\
\text { VECM }\end{array}$ & $\checkmark$ & $\checkmark$ & & \\
\hline Jin et al. (2018) & China & $1995-2012$ & $\begin{array}{l}\text { Cointegration, } \\
\text { GMM }\end{array}$ & $\checkmark$ & $\checkmark$ & & \\
\hline Akinwale (2018) & Saudi Arabia & $1980-2015$ & $\begin{array}{l}\text { ARDL, } \\
\text { Granger } \\
\text { causality test }\end{array}$ & & $\checkmark$ & $\checkmark$ & & & \\
\hline Saudi et al. (2019) & Indonesia & $1981-2017$ & $\begin{array}{l}\text { ARDL, } \\
\text { Granger } \\
\text { causality test }\end{array}$ & & $\checkmark$ & & & & \\
\hline Pan et al. (2019) & Bangladesh & $1976-2014$ & DAG,SVAR & $\checkmark$ & & & & & \\
\hline
\end{tabular}

Note: GMM=Generalized Method of Moments; ARDL=Autoregressive Distributed Lag; VECM=Vector Autoregressive Model; IAP=innovative accounting approach; PMG=Pooled Mean Group; DH= Dumitrescu and Hurlin; DAG= Directed acyclic graphs; SVAR= Structural Vector Autoregression; HV=Hurlin and Venet; OPEC= Organization of Petroleum Exporting Countries; NAFTA=North African Free Trade Area. 
Developed financial market stimulates energy demand through four different channels; (i) 'consumption effect' postulates that developed financial markets makes easier for consumers to purchase big items through the provision of cheaper loans that are large consumer of energy and can significantly enhances the total energy demand in a country; (ii) 'business effect' explains that developed financial markets makes easier and less expensive for businesses to borrow financial capital which can be utilized to expand existing businesses and create new ones (iii) 'wealth effect' shows increase in country's demand for energy due to increase in economic activities that is the result of consumers and investors' confidence on stock market activities (iv) 'technique effect' describes increase in energy efficiency in a country because developed capital markets encourage financial organization to finance in research and development activities to generate more efficient goods and services (Sadorsky, 2010 and 2011; Mankiw and Scarth, 2008).

Trade openness is considered to be a yardstick to measure the relative performance for an economy. Trade openness increases economic efficiency by utilizing resources effectively and exploit economies of scale (Wan et al. 2015). It increases energy demand through economies of scale, increase in the level of production and technological advancements (Cole, 2006; Nasreen and Anwar, 2014). Expansion in trade activities enhances economic activities which in turn positively impact energy consumption in domestic country (Shahbaz et al., 2014).

Technological progress is the key factor for reducing energy per unit of output (Khan et al. 2016; Jin et al.) because it has the tendency to generate solutions of enormous energy usage through the discovery of energy efficient techniques that may have the potential to reduce energy intensities at different scale of output (Jiahua et al. 2010). The interconnection of above-mentioned theoretical framework can be illustrated in a simple diagram portrayed in Fig.6. 
Fig.6: Interconnection between energy efficiency, financial development, trade openness and technological innovation

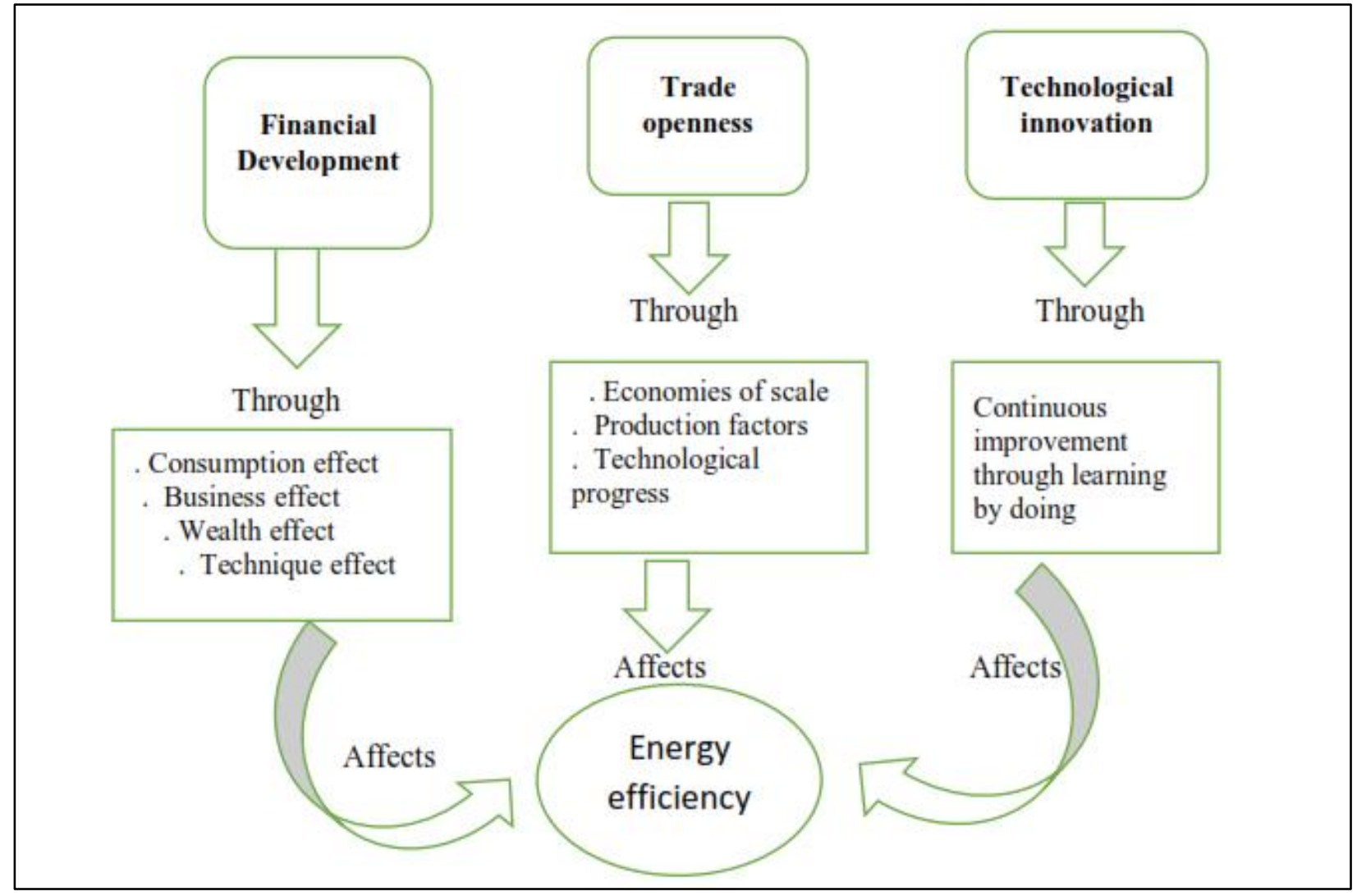

\section{2-Model Specification}

Following empirical literature and theoretical background, econometric model comprises energy efficiency (Eef) as dependent variable and economic growth (Egr), financial development (Fdev), trade openness ( Topen ) and technological innovation (Tinnov) as independent variables can be specified as follows:

$$
\text { Eef }_{t}=\gamma_{0}+\gamma_{1} \text { Fdev }_{t}+\gamma_{2} \text { Topen }_{t}+\gamma_{3} \text { Tinnov }_{t}+\gamma_{4} \text { Egr }_{t}+\mu_{t}
$$

The parameters $\gamma_{1}, \gamma_{2}, \gamma_{3}$ and $\gamma_{4}$ are long-term coefficients of financial development, trade openness, technological innovation and economic growth with respect to energy efficiency 
respectively. It is expected that financial development increases energy efficiency through the efficient utilization of resources (Tamazian et al. 2009) and hence $\gamma_{1}>0$, otherwise $\gamma_{1}<0$ when financial sector allocate funds to unproductive investment projects that utilize energy resources inefficiently (Zhang, 2011). The coefficient of $\gamma_{2}>0$ when trade openness helps to increase energy efficiency through the transfer of modern technology from advanced economies to less developed economies (Wing, 2008; Gomez and Rodriguez, 2019) and $\gamma_{2}<0$ when production structure of an economy is moving from labor intensive to capital intensive one (Cole, 2006; Hubler and Keller, 2010). The coefficient of $\gamma_{3}>0$ because technological innovations help to generate solution to energy dependence through the discoveries of energy efficient technical advancements that have the tendency to increase energy efficiency (Bosetti et al., 2006). The coefficient of $\gamma_{4}>0$ because increase in the range of economic activities in developing countries due to structural changes increase energy consumption more than output growth which in turn reduces energy efficiency (Huang et al. 2008; Mehmood and Kanwal, 2017).

\section{3- Description of Variables and Data Sources}

a) Financial Development ( Fdev)

Development of financial markets can be best measured by the level of transaction costs, financial intermediaries' ability to mobilize domestic savings, manage risks and facilitates transactions (Beck et al., 2000). Unfortunately, there is no reliable availability of data to support this idea. Researchers used different proxies to measure the level of financial deepening in a country (Ang and Mckibbin, 2007). 
The most popular indicator of financial depth is 'Liquid Liabilities' and suggested by Levine, (2003); Beck et al., (2000). Other widely used measure is 'Private Credit' and used by Sadorsky, (2010) and (2011); Gomez and Rodriguez, (2019); Pen et al. (2019). The third one indicator used to measure financial depth is 'Commercial-Central Bank Assets' used by Huang and Temple, (2005) and Hanh (2010). It helps the financial intermediaries to utilize savings into productive investment, monitor the performance of firms and encourage corporate governance. The fourth one indicator is 'Stock Market Capitalization'. 'Total Value Traded' is the final indicator used to measure financial depth. The last two indicators measure stock market activity as reported by Sadorsky, (2010) and (2011).

The next three indicators measure the efficiency of financial sector. The first one is 'Overhead Cost' and the second indicator is 'Net Interest Margin'. Lower value of both these indicators represents the greater competition and efficiency in banking sector (Huang and Temple, 2005; and Hanh, 2010). The third indicator is 'Turnover Ratio' and a high value of this indicator represent the equity market is more efficient (Sadorsky, 2010 and 2011). Following the studies of Huang and Temple (2005), Ang and Mckibbin (2007) and Hanh (2010), we aggregate the abovementioned indicators into new measures of financial development by using principal component analysis (PCA). PCA reduce the dimension of data and combine them in to a single index, while at the same time the potential problem of multicollinearity by including more than one proxies in a given model can be reduced (Lenka, 2015). Appendix Table-A4 reports the results of PCA that are used to develop the index of financial development.

b) Trade openness (Topen ) 
Trade openness is simply the ratio of trade to GDP and is used by Kim et al. (2010); Nasreen and Anwar, (2014); Pen et al. (2019) and others in research.

c) Technological Innovation (Tinnov)

Empirical studies have used patents as a proxy for innovation (see, e.g. Ali et al. 2016; Saudi et al. 2019; Pen et al. 2019) because patent shows the range of research and development activities and sources of technology in an economy (Acs, 2002) and we also use this proxy in the present paper.

d) Energy Efficiency ( Eef )

Energy intensity defined as a ratio of energy consumption to GDP is used to measure energy efficiency (Stern, 2006; Fisher-Vanden, 2007; Lescaroux, 2008) and we also use this measure in the present paper.

e) Economic Growth ( $E g r)$

The last variable in our methodology is economic growth measured by GDP per capita (constant 2015 US\$) and used by Nasreen and Anwar, (2014); Pen et al. (2017); Saudi et al. (2019) and others.

Annual data covering the period 1985-2017 on trade openness, technological innovation and economic growth are retrieved from World Development Indicators (WDI), financial development indicators $^{1}$ from Global Financial Development Database (GFDD) and energy efficiency from International Energy Agency (IEA). Natural logarithmic form of all variables except financial development index is used in empirical analysis. The summary statistics of the data used in this study are shown in Appendix, Table a.1.

\footnotetext{
${ }^{1}$ All financial development indicators are used $\%$ of GDP.
} 


\section{4-Research Methods}

The foremost step in research methodology is the application of unit root tests. $\mathrm{ADF}^{2}$ and $\mathrm{PP}^{3}$ unit root tests are extensively used in empirical literature. However, one of the main shortcomings for these tests is that they do not take into account the endogenous structure breaks in the series. Thus, their outcomes provide misleading conclusion. To overcome this shortcoming, we have applied $\mathrm{ZA}^{4}$ unit root test that accommodate structure break in the series.

The second step in research methodology is the application of cointegration technique. Johansen cointegration approach is more commonly used by energy economists and also suitable for present analysis. Our data covers the period of more than 30 years, there is possibility of structure breaks in cointegration relationship. Hence, Gregory and Hansen (1996) residual based cointegration approach with regime shift is applied to check the robustness of cointegration results. The detail of unit root and cointegration tests is not provided here because these are most common tests and well documented in empirical literature.

In the next step, DAG method is applied to explore the contemporaneous causal linkages between selected variables. The fundamental feature of DAG approach is that arrows are used to show the direction of causality between variables. No edge $(\mathrm{X}-\mathrm{Y})$ indicates the absence of interaction between $\mathrm{X}$ and $\mathrm{Y}$. Undirected edge $(\mathrm{X} \rightarrow \mathrm{Y})$ signifies that $\mathrm{X}$ causes $\mathrm{Y}$ whereas bidirected edge $(\mathrm{X} \leftrightarrow \mathrm{Y})$ denotes bidirectional causality between $\mathrm{X}$ and $\mathrm{Y}$. A PC algorithm is used to generate directed graphs in the updated version of TEDRAD program. The algorithm firstly generates a complete undirected graph in which each variable is connected with other variables through edges and check the correlation between pairs of variables. If first order conditional correlation between

\footnotetext{
${ }^{2}$ Augmented Dickey Fuller

${ }^{3}$ Philips and Perron

${ }^{4}$ Zivot Andrew
} 
variables is zero, the algorithm removes the edges in undirected graph. Subsequently, the second order partial correlation between variables is tested and so on.

The dynamic relationship among macroeconomic variables is commonly studied by applying VAR model. The main drawback with simple VAR is that it cannot explain the contemporaneous relationship between variables. To overcome this disadvantage, we have applied SVAR as suggested by Sims (1986) to examine the contemporaneous causal relationship between variables in the final step. SVAR model can be expressed as follows:

$$
B_{0} K_{t}=d_{0}+\sum_{i=1}^{m} B_{i} K_{t-i}+v_{t}
$$

Where $K_{t}$ is $5 \times 1$ vector that comprises five selected variables, $B_{0}$ is $5 \times 5$ instantaneous matrix, $d_{0}$ is $5 \times 1$ vector of constant and $B_{i}$ is a $5 \times 5$ autoregressive coefficient matrix and $v_{t}$ is the $5 \times 1$ vector of structural disturbances. Structural disturbances have zero covariances and are serially uncorrelated. The direct estimation of SVAR is difficult, thus, reduced form of SVAR is used to estimate the impulse response function. For this purpose, we have multiplied both sides of Eq. 2 by $B_{0}^{-1}$ and obtain the following:

$$
K_{t}=j_{0}+\sum_{i=1}^{m} \alpha_{i} K_{t-i}+\mu_{t}
$$

Where $j_{0}=B_{0}^{-1} d_{0}, \alpha_{i}=B_{0}^{-1} B_{i}$ and $\mu_{t}=B_{0}^{-1} v_{t}$. In regression framework, impulse response function is generated by this SVAR. SVAR also help to calculate variance decomposition that shows how shocks reverberate in a system. Above mentioned research methods and steps are presented in Fig. 7. 
Fig. 7: Overview of estimation methods

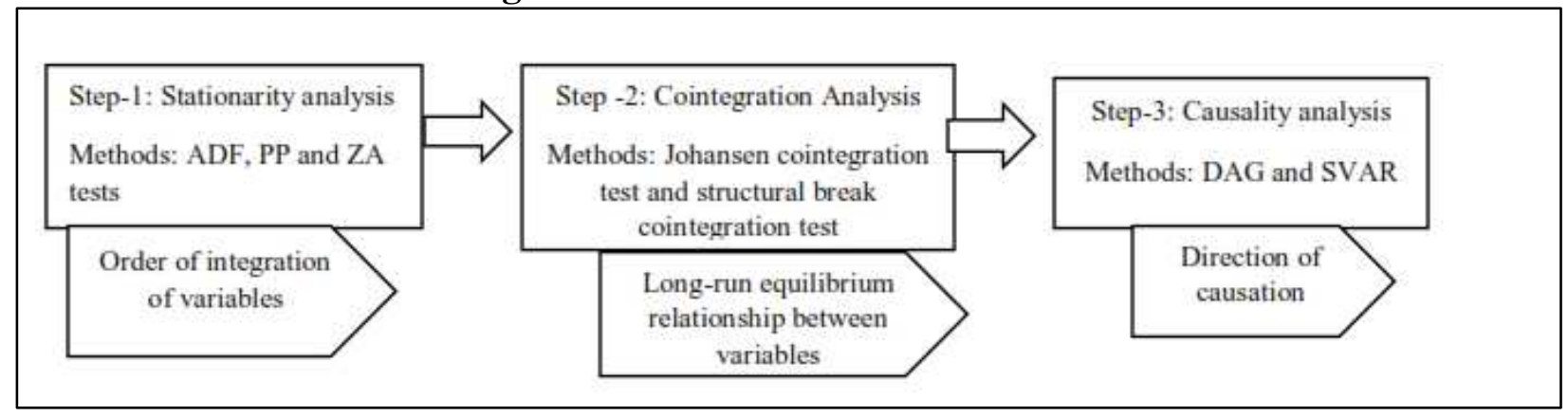

\section{5-Results and Discussions}

The findings of ADF, PP and ZA unit root tests are reported in Table 2. The numerical estimates are in strong favor of non-stationary at level while stationary at first difference. Thus, it is reasonably to conclude that despite the evidence of structural breaks, all the variables ( $\operatorname{Eef}_{t}, F d e v_{t}$ ,Topen ${ }_{t}$, Tinnov $_{t}$, Egr $\left.r_{t}\right)$ are I(1).

Table-2: Unit Root Results

\begin{tabular}{|l|l|l|l|l|l|l|l|l|l|l|l|}
\hline \multirow{2}{*}{ Variable } & \multicolumn{3}{|c|}{ ADF test } & \multicolumn{4}{c|}{ PP test } & \multicolumn{5}{c|}{ ZA test } \\
\cline { 2 - 12 } & Level & $1^{\text {st }}$ diff. & $\mathrm{k}$ & Level & $1^{\text {st }}$ diff. & $\mathrm{k}$ & Level & S.B & $1^{\text {st }}$ diff. & S.B & $\mathrm{k}$ \\
\hline Eef $_{t}$ & -0.554 & $-4.091^{*}$ & 1 & -1.187 & $-3.581^{* *}$ & 1 & -3.330 & 1993 & $-6.905^{*}$ & 1993 & 0 \\
\hline Fdev $_{t}$ & -0.940 & $-3.886^{* *}$ & 0 & -1.055 & $-3.588^{* *}$ & 1 & -4.762 & 2002 & $-5.426^{* *}$ & 2005 & 0 \\
\hline Topen $_{t}$ & -0.683 & $-3.490^{* * *}$ & 1 & -1.868 & $-4.206^{*}$ & 1 & -3.607 & 2005 & -8.542 & 2008 & 0 \\
\hline Tinnov $_{t}$ & -0.572 & $-3.621^{* *}$ & 1 & -1.577 & $-3.509 * *$ & 2 & -3.165 & 2006 & $-5.087 * *$ & 1999 & 0 \\
\hline Egr $_{t}$ & -0.185 & $-3.653^{* *}$ & 1 & -0.534 & $-3.301^{* *}$ & 1 & -3.908 & 1997 & $5.781^{*}$ & 2003 & 1 \\
\hline
\end{tabular}

Note: $\mathrm{k}$ represents optimal lag order; S.B shows break point; $* * *$ and $* * *$ denote stationarity of the series at $1 \%, 5 \%$ and $10 \%$ level respectively.

The I(1) series allows us to procced for the application of cointegration. Johansen cointegration is applied to examine the long-run association between variables. The outcome explains that there is evidence of cointegration among Eef $f_{t}$, Fdev $_{t}$, Topen $_{t}$, Tinnov $_{t}$ and $E g r_{t}$ in Pakistan. 
Table-3: Results of Johansen Cointegration Test

\begin{tabular}{|l|l|l|l|l|}
\hline Hypothesis & Trace statistics & $5 \%$ critical value & $\begin{array}{l}\text { Max-Eigen } \\
\text { statistics }\end{array}$ & $5 \%$ critical value \\
\hline$r=0$ & $79.71^{*}$ & 69.18 & $38.71^{*}$ & 33.87 \\
\hline$r \leq 1$ & 41.00 & 47.85 & 27.23 & 27.58 \\
\hline$r \leq 2$ & 13.77 & 29.79 & 7.455 & 21.13 \\
\hline$r \leq 3$ & 6.318 & 15.49 & 5.125 & 14.26 \\
\hline$r \leq 4$ & 0.037 & 3.841 & 1.189 & 3.841 \\
\hline
\end{tabular}

Note: $*$ indicate rejection of null at $5 \%$ significance level.

Johansen test do not take into account the evidence of structural breaks in the long-run relationship.

This shortcoming demands the application of more robust and rigorous cointegration test that produce reliable estimates in the presence of structural break. As a consequence, we have applied a Gregory-Hansen cointegration test. This test allows endogenous structural breaks in cointegrating vector. The results depicted in Table 4 show that the evidence of cointegration can be clearly seen in third model (model C/S) while structural break exist in all three models. The evidence of breaks in the system suggest that we need to be taken care of structural breaks in the specification of energy-finance-trade-technology-growth relationship in Pakistan.

Table-4: Results of Gregory-Hansen Structural Break Cointegration Test

\begin{tabular}{|l|l|l|l|l|l|l|}
\hline Model & ADF $^{*}$ & S.B. & $Z_{t}^{*}$ & S.B. & $Z_{a}^{*}$ & S.B. \\
\hline C & -5.45 & 1999 & -4.68 & 1993 & -27.09 & 1993 \\
\hline C/T & $-6.03^{*}$ & 1996 & -5.21 & 1992 & -31.19 & 1992 \\
\hline C/S & $-6.91^{*}$ & 1993 & $-7.02^{*}$ & 1992 & -40.10 & 1992 \\
\hline
\end{tabular}

Note: S.B shows break point ;* indicates $5 \%$ level of significance.

The findings of long-run responsiveness of energy efficiency to change in financial development, trade openness, technological innovation and economic growth obtained from normalized cointegration equation are given in Table 5. The results show that development of financial sector enhances energy efficiency in Pakistan. Specifically, it reveals that energy efficiency increases by $0.476 \%$ to a $1 \%$ improvement in financial sector development. The evidence supports the recent 
development in financial market of Pakistan that is the result of financial reforms under which payment systems are modernized, technological infrastructure is improved, micro-prudential regulation system is strengthen, foreign currency deposits are legalized and more opportunities are provided for domestic borrowers to borrow loans and utilize them on productive investment projects. The empirical finding is in line with those of Farhani and Solarin (2017), Ouyang and Li (2018), Gomes and Rodriguez (2019). The coefficient of trade openness is inversely associated with energy efficiency, that is energy efficiency decreased by $0.607 \%$ due to $1 \%$ increase in trade openness. The result implies that Pakistan is in the process of industrialization and its more emphasis is on capital intensive industries that use energy as an input to produce goods and services. This inference is consistent with those of Cole, (2006); Nasreen and Anwar, (2014). Technological innovation is significantly improving energy efficiency by decreasing energy demand in Pakistan. The result support the findings of Sohag et al. (2015) and Wei et al. (2016). The estimate of economic growth shows negative and significant impact on energy efficiency which is the result of increase in output growth that demand more energy in Pakistan. The result corroborates the conclusion of Huang et al. (2008); Mehmood and Kanwal, (2017); Gomes and Rodriguez (2019).

Table-5: Long-run Estimates

\begin{tabular}{|l|l|l|l|l|l|}
\hline Variable & Fdev $_{t}$ & Topen $_{t}$ & Tinnov $_{t}$ & Egr $_{t}$ & Constant \\
\hline Coefficient & $0.467 *$ & $-0.607^{* *}$ & $0.800^{*}$ & $-0.714^{*}$ & $1.672^{* * *}$ \\
\hline S.E. & 0.118 & 0.231 & 0.107 & 0.166 & 0.873 \\
\hline
\end{tabular}

Note: $* * *$ and $* * *$ indicate $1 \%, 5 \%$ and $10 \%$ level of significance.

We have applied DAG analysis to explore contemporaneous causal flows among $E e f_{t}, F d e v_{t}$, Topen $_{t}$, Tinnov ${ }_{t}$ and Egr $r_{t}$ in Pakistan. The outcome of DAG analysis is the VAR residual correlation matrix, shown in Appendix Table a.3. Firstly, undirected graph in which each variable is connected with other variable is created (see Fig. 8(a)). Then, edges between variables are 
removed and contemporaneous causal flow is determined by applying PC algorithm (1997). Fig 8(b) shows different patterns of contemporaneous causality among five variables. For instance, financial development influence energy efficiency (Boutabba, 2014; Mahalik et al. 2017; Paramati et al. 2017) through consumption, wealth and business effect of financial development. International trade is connected with energy efficiency, financial development, output growth and technological innovation. The results indicate the knowledge spillover and production impact of international trade. The finding corroborates the result regarding the connectedness of trade openness to energy efficiency advanced by Rafiq et al. (2016) and Akhtar et al. (2016); from trade openness to financial development advocated by Nasreen and Anwar (2017); from trade openness to output growth presented by Ali et al. (2016); from trade openness to technological progress found by Pen et al. (2019). In terms of technological innovation, there is connection from technological innovation to energy efficiency and result validates the finding of Wei et al. (2016).

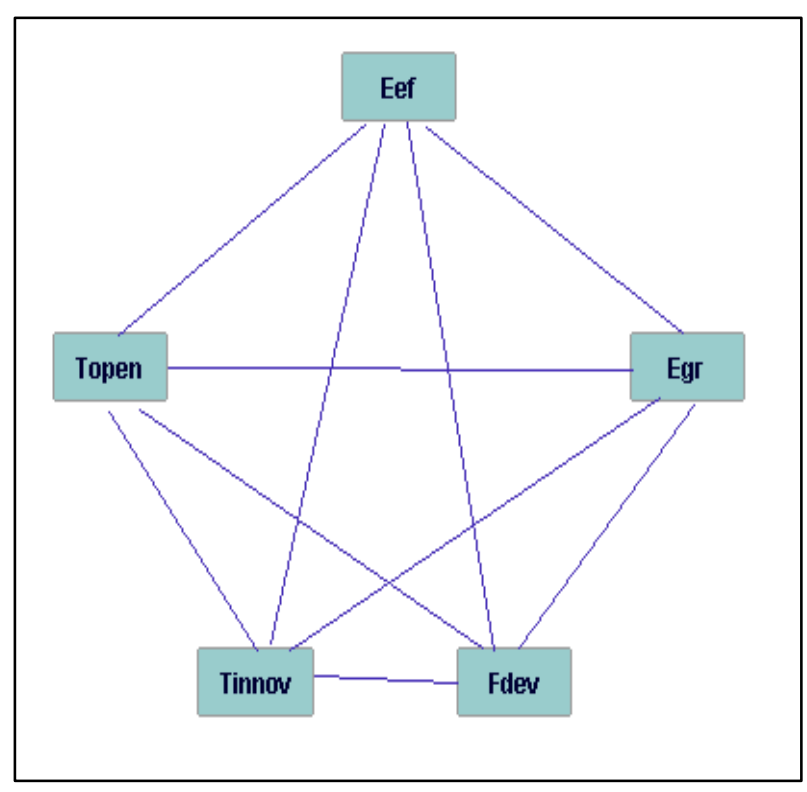

Fig.8 (a): Complete undirected graph of Eef $_{t}$, Fdev $_{t}$, Topen $_{t}$, Tinnov $_{t}$, Egr $_{t}$

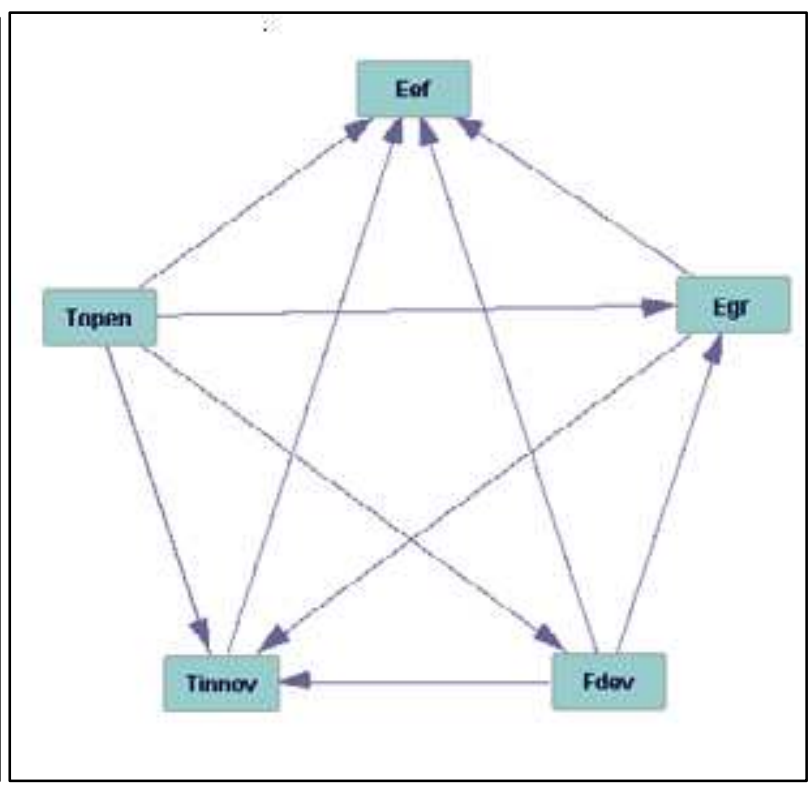

Fig.8(b): Directed acyclic graph of Eef $_{t}$, Fdev $_{t}$, Topen $_{t}$, Tinnov $_{t}$, Egr $_{t}$ 
Moreover, financial development has linked with technological innovation which is the results of research and development activities generated through the transfer of funds from financial institutions and in line with the finding of Hsu et al. (2014). Financial development also connected with economic growth because it provides funds for investment to domestic and foreign investor and support the results of Levine, (2003); Ang, (2008); Hsueh et al. (2013). Moreover, economic growth influence energy efficiency but energy efficiency has no impact on economic growth. The result validates the conclusion of Cantore et al. (2016); Pen et al. (2019).

The contemporaneous causality results investigated from DAG are used to estimate the variance decomposition of SVAR in order to study the dynamic association among $\operatorname{Eef}_{t}$, Fdev $_{t}$, Topen $_{t}$, Tinnov $_{t}$ and Egr $_{t}$ in Pakistan (see Table 6). For this purpose, we took 20 years and divide them into three periods: year 1 (contemporaneous), year 2 to 5 (short term) and year 10 to 20 (long term) following Pen et al. (2019). Panel-a of Table 6 suggest that technological advancements have greater impact on energy efficiency $(26.77 \%)$ in contemporaneous time while the impact of financial development, output growth and trade is $0.09 \%, 0.36 \%$ and $1.34 \%$ respectively during the same period. Advancement in technology has strong impact on energy efficiency in short-run while trade openness and financial development has strong impact on energy efficiency in longterm. The impact of economic growth on energy efficiency increases till mid-term but gradually decreases in long-term. Panel-b of Table 6 show that financial development is only influenced by energy efficiency and income growth in the first year of forecast period. But with the increase in forecast period, the influence of trade openness and technological innovation become significant.

Panel-c of Table 6 shows that technological invention is influenced by financial sector development and income growth to a greater extent while with energy efficiency and trade openness to a lesser extent at contemporaneous period. However, a substantial impact of trade 
openness and energy efficiency on technological innovation is seen in long time period. Panel-d of Table 6 illustrate the variance decomposition of trade openness. Trade openness is highly affected by financial development $(20.11 \%)$ and technological innovation $(12.43 \%)$ in medium term, energy efficiency (23.52\%) in long-term and economic growth (14.41\%) in contemporaneous period. Panel-c of said Table illustrate that economic growth is influenced by itself and energy efficiency in contemporaneous time, but in the long run (20 years) it is influenced by financial development (5.52\%), trade liberalization (45.85\%) and technological progress $(2.39 \%)$.

Table-6: Results of Variance Decomposition Based on DAG

\begin{tabular}{|c|c|c|c|c|c|c|c|c|c|c|c|}
\hline \multicolumn{6}{|c|}{ Panel-a: Variance decomposition of $E e f_{t}$} & \multicolumn{6}{|c|}{ Panel-b: Variance decomposition of $F d e v_{t}$} \\
\hline Period & $E e f_{t}$ & $F d e v_{t}$ & Topen $_{t}$ & Tinnov $_{t}$ & $E g r_{t}$ & Period & $E e f_{t}$ & $F d e v_{t}$ & Topen $_{t}$ & Tinnov $_{t}$ & $E g r_{t}$ \\
\hline 1 & 55.84 & 0.09 & 1.34 & 26.77 & 0.36 & 1 & 0.88 & 88.99 & 0.00 & 0.00 & 10.12 \\
\hline 2 & 52.58 & 1.47 & 4.31 & 38.64 & 0.72 & 2 & 0.79 & 81.07 & 7.03 & 0.69 & 10.40 \\
\hline 5 & 49.79 & 1.89 & 16.75 & 26.51 & 0.70 & 5 & 1.39 & 64.53 & 20.53 & 0.30 & 13.22 \\
\hline 10 & 45.35 & 5.34 & 32.10 & 12.66 & 0.43 & 10 & 12.33 & 43.58 & 26.51 & 2.47 & 15.09 \\
\hline 20 & 41.43 & 6.48 & 41.67 & 7.20 & 0.20 & 20 & 24.30 & 30.14 & 20.45 & 15.96 & 9.13 \\
\hline \multicolumn{6}{|c|}{ Panel-c: Variance decomposition of Tinnov $_{t}$} & \multicolumn{6}{|c|}{ Panel-d: Variance decomposition of Topen $_{t}$} \\
\hline Period & $E e f_{t}$ & $F d e v_{t}$ & Topen $_{t}$ & Tinnov $_{t}$ & $E g r_{t}$ & Period & $E e f_{t}$ & $F d e v_{t}$ & Topen $_{t}$ & Tinnov $_{t}$ & $E g r_{t}$ \\
\hline 1 & 0.15 & 3.36 & 0.00 & 93.15 & 3.32 & 1 & 2.47 & 11.35 & 71.21 & 0.54 & 14.41 \\
\hline 2 & 1.60 & 15.30 & 1.30 & 62.04 & 19.74 & 2 & 1.74 & 11.84 & 67.93 & 8.60 & 9.87 \\
\hline 5 & 8.48 & 27.69 & 2.27 & 32.62 & 28.92 & 5 & 2.34 & 20.11 & 55.24 & 12.43 & 9.84 \\
\hline 10 & 7.69 & 32.37 & 1.92 & 31.45 & 26.55 & 10 & 5.95 & 9.88 & 51.37 & 11.69 & 9.88 \\
\hline 20 & 17.96 & 25.74 & 9.35 & 27.65 & 19.27 & 20 & 23.52 & 5.59 & 47.53 & 8.81 & 5.97 \\
\hline
\end{tabular}

\begin{tabular}{|l|l|l|l|l|l|}
\hline \multicolumn{6}{|l|}{ Panel-e: Variance decomposition of Egr $_{t}$} \\
\hline Period & Eef $_{t}$ & Fdev & Topen $_{t}$ & Tinnov $_{t}$ & Egr $_{t}$ \\
\hline 1 & 9.78 & 0.00 & 0.00 & 0.00 & 90.21 \\
\hline 2 & 24.37 & 7.44 & 7.67 & 1.96 & 58.55 \\
\hline 5 & 40.53 & 14.96 & 21.28 & 1.36 & 21.85 \\
\hline 10 & 39.86 & 7.07 & 40.34 & 0.50 & 12.21 \\
\hline 20 & 40.40 & 5.52 & 45.85 & 2.39 & 5.82 \\
\hline
\end{tabular}




\section{6-Conclusion and Policy Implications}

The importance of energy for economy and finite nature of primary energy resources turned the attention of international economies to achieve energy efficiency and to reduce energy usage in economic activities. Motivated by these facts, this study examines the dynamic linkages among energy efficiency, financial development, international trade and technological innovation by incorporating economic growth as an auxiliary variable using yearly data for the period 19802017. To achieve inferences of the study, we have examined the stationarity of the series, evidence of cointegration and contemporaneous causal flows among variables. Traditional unit root tests (ADF and PP) and structural break unit test (ZA) indicate that series of Eef $f_{t}$, Fdev $_{t}$, Topen $_{t}$, Tinnov $v_{t}$ and $E g r_{t}$ are I(1). Johansen cointegration and Gregory-Hansen structural break cointegration methods confirm the evidence of cointegration among variables. In addition, the study signifies that financial development and technological innovation promote energy efficiency while international trade and economic growth are detrimental for energy efficiency. Finally, contemporaneous causal linkages among variables is explored by applying DAG and SVAR models. The DAG results explain that energy efficiency is connected with financial sector development, trade liberalization, technological advancements and output growth. At the same time, developed financial market, trade liberalization strategies and improvement in economic growth encourage advancement in technology. The findings of SVAR variance decomposition reveal that technological innovation has greater impact on energy efficiency in short-term while financial development and trade openness has greater impact on energy efficiency in long-term. Similarly, economic growth explains mix evidence with respect to energy efficiency, its effect increases in medium-term and decrease in long-term. 
Finally, the policy implications based on empirical findings are summarized as follows: firstly, our results explain that financial development and technological innovation has positive impact on energy efficiency. In this regard, those policies may be formulated that encourage the efficient energy technologies and effective management practices on both demand side and supply side. As a consequences, there is need to (i) monitor energy efficiencies in major energy consuming industrial units to ensure the performance of operating parameters are energy efficient, (ii) change work practices such as at home or/ at work places, (iii) choose different modes of transport such as public transport instead of cars, rail instead of road for freight etc. (iv) use energy efficient equipment both at home and offices (v) more efficient energy generation system that minimize heat waste (vi) more efficient transmissions and distribution system for better routine data acquisition and analysis. Apart from these, financial organization may be encouraged to increase their financing in those projects that promote energy saving technologies in Pakistan. Secondly, our results demonstrate that economic growth and international trade has negative impact on energy efficiency. This is because, Pakistan is in the phase of transition, the demand for energy which is the key industrial input is increasing day by day. Energy efficient and energy conversation policies are critical to achieve sustainable development of Pakistan. Furthermore, trade policies that encourage the implant of innovative technologies in industries are need to be formulated. Finally, government should introduce incentive and penalty mechanism to support improved energy efficiency, promote and facilitate international collaboration and corporation and raise awareness of energy usage and related aspect of energy efficiency among users. 


\section{Declaration}

- Availability of data and material: Will be Available on request

- Competing interests: 'Not applicable'

- Funding: 'Not applicable'

- Authors' contributions: Samia Nasreen: Conceptualization, Methodology, Software, Investigation, Supervision, Reviewing and Editing. Writing- Original draft preparation Sofia Anwar: Data curation, Writing- Original draft preparation.

- Acknowledgements: 'Not applicable'

\section{References}

1. Acs ZJ, Anselin L, Varga A. (2002). Patents and innovation counts as measures of regional production of new knowledge. Resource Policy, 31(7), 1069-85.

2. Ali W, Abdullah A, Azam M. (2016). The Dynamic Linkage between Technological Innovation and carbon dioxide emissions in Malaysia: An Autoregressive Distributed Lagged Bound Approach. International Journal of Energy Economics and Policy, 6(3), $389-400$

3. Al-Mamun M, Sohag K, Mia MAH, Uddin GS, Ozturk I. (2014). Regional differences in the dynamic linkage between $\mathrm{CO} 2$ emissions, sectoral output and economic growth. Renewable and Sustainable Energy Review, 38,1-11.

4. Akhtar MH, Sheikh MR, Altaf A. (2016). Financial Development, Energy Consumption and Trade Openness Nexus: Empirical Evidence from Selected South Asian Countries. Pakistan Journal of Social Sciences, 36 (1), 505-518.

5. Akinwale, Y. O. (2018). An Empirical Analysis of Short Run and Long Run Relationships between Energy Consumption, Technology Innovation and Economic Growth in Saudi Arabia. International Journal of Energy Economics and Policy, 8(4), 139-146.

6. Ang JB. (2008). A survey of recent development in the literature of finance and growth. Journal of Economic Surveys, 22 (3), 536-576.

7. Ang JB, McKibbin WJ. (2007). Financial liberalization, financial sector development and growth: evidence from Malaysia. Journal of development economics,84(1), 215-233.

8. Arif I, Kazmi SW, Khan L, (2017). Relationship Between Trade Openness and Energy Consumption in Oil Importing Asian Countries. Journal of Finance \& Economics Research, 2(1), 33-42.

9. Athukorala P, Wilson C. (2010) Estimating short and long-term residential demand for electricity: New evidence from Sri Lanka. Energy Economics, 32, 34-40.

10. Beck T, Levine R, Loayza N. (2000). Finance and the sources of growth. Journal of Financial Economics 58, 261-300.

11. Bekhet H A, Matar A, Yasmin T. (2017). CO2 Emissions, Energy Consumption, Economic Growth, and Financial Development in GCC countries: Dynamic Simultaneous Equation Models. Renewable and Sustainable Energy Review, 70, 117-132.

12. Bosetti V. Carraro C. Galeotti M, Massetti E, Tavoni M. (2006). WITCH: a world induced technical change hybrid model. The Energy Journal, 27(2), 13-38. 
13. Boutabba M.A. (2014). The impact of financial development, income, energy and trade on carbon emissions: evidence from the Indian economy. Econ Modelling, 40, 33-41.

14. C Ma, Stern DI. (2006). China's changing energy intensity trend: a decomposition analysis. Energy Economics, 30(3), 1037-53.

15. Coban S, Topcu M. (2013). The nexus between financial development and energy consumption in the EU: a dynamic panel data analysis. Energy Economics, 39, 81-8.

16. Chang SC. (2015). Effects of financial developments and income on energy consumption. International Review of Economics and Finance, 35, 28-44.

17. Cole MA. (2006). Does trade liberalization increase national energy use? Economic Letter, 92, 108-12.

18. Farhani S, Solarin SA. (2017). Financial development and energy demand in the United States: new evidence from combined cointegration and asymmetric causality tests. Energy, 134,1029-37.

19. Fei Q, Rasiah R. (2014). Electricity Consumption, Technological Innovation, Economic Growth and Energy Prices: Does Energy Export Dependency and Development Levels Matter? Energy Procedia, 61, 1142-1145.

20. Fisher-Vanden K, Jefferson GH, Liu H, Tao Q. (2004). What is driving China's decline in energy intensity? Resource and Energy Economics, 26(1), 77-97.

21. Ghani GM. (2012). Does trade liberalization effect energy consumption. Energy Policy, 43:285-90.

22. Gómez M, Rodríguez JC. (2019). Energy Consumption and Financial Development in NAFTA Countries, 1971-2015. Applied Sciences, 9, 302; doi:10.3390/app9020302.

23. Gregory AW, Hansen BE. (1996). Residual based tests for cointegration in models with regime shift. Journal of Econometrics, 70(1), 99-126.

24. Halicioglu F. (2011). A dynamic study of income, energy and exports in Turkey. Energy, 36, 3348-3354.

25. Hang L, Tu M. (2007). The impacts of energy prices on energy intensity: evidence from

26. China. Energy Policy, 35(5), 2978-88.

27. Hanh PTH. (2010). Financial development, financial openness and trade openness: New evidence. FIW Working Paper No.60.

28. Haun and Temple (2005). Does external trade promote financial development? Discussion Paper No. 05/575, Department of economics, university of Bristol 8 woodland Road Bristol.

29. Hubler EM, Keller A. (2010). Energy saving via FDI? Empirical evidence from developing countries. Environment and Development Economics, 15(1), 59-80.

30. Hsu P, Tian X, Xu Y. (2014). Financial development and innovation: cross-country evidence. Journal of Financial Economics, 112, 116-35.

31. Hsueh SJ, Hu YH, Tu CH. (2013). Economic growth and financial development in Asian countries: A Bootstrap panel Granger causality analysis. Economic Modelling, 32, 294301.

32. Huang BN, Hwang M.J, Yang C W. (2008). Causal relationship between energy consumption and GDP growth revisited: A dynamic panel data approach. Ecological Economics, 67(1), 41-54. 
33. Irandoust M. (2016). The renewable energy-growth nexus with carbon emissions and technological innovation: Evidence from the Nordic countries. Ecological Indicator, 69, $118-125$.

34. Jena PR, Grote U. (2008). Growth-trade-environment nexus in India. Economics Bulletin, 17(11), 1-11.

35. Jiahua P, Guiyang Z, Yan Z, ShouXian Z, Qianyi X. (2010). Clarification of the concept of low-carbon economy and analysis of its core elements. International Economic Review,4,88-102.

36. Jibrilla JJ. (2018). Does Trade Liberalization Affect Energy Saving in Nigeria? Pakistan Journal of Humanities and Social Sciences, 6(4), 493 - 515.

37. Jin, W, Zhang ZX. (2014) Quo Vadis? Energy Consumption and Technological Innovation in China's Economic Growth, CCEP Working Paper 1412, August 2014. Crawford School of Public Policy, The Australian National University.

38. Jin L, Duan K, ID and Tang X. (2018). What is the Relationship between Technological Innovation and Energy Consumption? Empirical Analysis Based on Provincial Panel Data from China. Sustainability, 10, 145; doi:10.3390/su10010145.

39. Lenka SK. (2015). Measuring Financial Development in India, A PCA Approach. Theoretical and Applied Economics, XXII(602), 187-198.

40. Khan G, Ahmad AM, Kiani A. (2016). Dynamics of Energy Consumption, Technological Innovations and Economic Growth in Pakistan. Journal of Business \& Economics, 8(1), 129.

41. Kim DH, Lin SC, Suen YB. (2010). Dynamic effects of trade openness on financial development. Economic Modelling, 27(1), 254-61.

42. Koengkan M. (2018). The positive impact of trade openness on consumption of energy: Fresh evidence from Andean community countries. Energy 158(1):936-943.

43. Kyophilavong P, Shahbaz M, Anwar S, Masood S. (2015). The energy-growth nexus in Thailand: does trade openness boost up energy consumption? Renewable and Sustainable Energy Review 46, 265-74.

44. Lau,L-S, Yii K-J, Lee C-Y, Ching Y-L. Lee E-H. (2018). Investigating the Determinants of Renewable Energy Consumption in Malaysia: An ARDL Approach. International Journal of Business and Society, 19(3), 886-903.

45. Lescaroux F. (2008). Decomposition of US manufacturing energy intensity and elasticities of components with respect to energy prices. Energy Economics, 30(3), 1068-80.

46. Levin R. (2003). More on finance and growth: more finance, more growth? Federal Reserve Bank of St. Louis Review, 85, 31-46.

47. Mahalik MK, Mallick H. (2014). Energy consumption, economic growth and financial development: exploring the empirical linkages for India. Journal of Developing Areas, 48(4), 139-159.

48. Mahalik MK, Babu MS, Loganathan N, Shahbaz M. (2017). Does financial development intensify energy consumption in Saudi Arabia? Renewable and Sustainable Energy Review, 75, 1022-34.

49. Mahmood T, Kanwal F. (2017). Long Run Relationship between Energy Efficiency and Economic Growth in Pakistan: Time Series Data Analysis. Forman Journal of economic Studies, 13, 105-120.

50. Mankiw NG, Scarth W. (2008). Macroeconomics: Third Canadian Edition Worth Publishers, New York. 
51. Masih AMM, Masih R. (1998). A multivariate cointegrated modeling approach in testing temporal causality between energy consumption, real income and prices with an application to two Asian LDCs. Applied Economics, 30(10),1287-9.

52. Mukhtarov S, Mikayilov JI, Mammadov J, Mammadov E. (2018). The Impact of Financial Development on Energy Consumption: Evidence from an Oil-Rich Economy. Energies, 11, 1536, doi:10.3390/en11061536.

53. Najarzadeh R, Reed M, Khoshkhoo A, Gallavani A. (2015). Trade and Energy Consumption in the OPEC countries. Journal of Economic Cooperation and Development, $36(1), 89-102$.

54. Nasreen S, Anwar S. (2014). Causal relationship between trade openness, economic growth and energy consumption: A panel data analysis of Asian countries. Energy Policy, 69, 8291.

55. Nasreen S, Anwar S. (2017), Financial Stability and the Role of Economic and Financial Integration in South Asia: Evidence from Time-Series Data, Singapore Economic Review, 63(1), 1-31.

56. Ouyang Y, Li P. (2018). On the nexus of financial development, economic growth, and energy consumption in China: New perspective from a GMM panel VAR approach. Energy Econ. 71-238-252.

57. Pan X, Ai B, Li C, Pan X, Yan Y. (2017). Dynamic relationship among environmental regulation, technological innovation and energy efficiency based on large scale provincial panel data in China. Technol Forecasting and Social Change, 12, 012.

58. Pan X, Uddin MK, Han C, Pan X. (2019). Dynamics of financial development, trade openness, technological innovation and energy intensity: Evidence from Bangladesh. Energy, 171, 456-464.

59. Paramati SR, Apergis N, Ummalla M. (2017). Financing clean energy projects through domestic and foreign capital: The role of political cooperation among the EU, the G20 and OECD countries. Energy Economics, 61, 62-71.

60. Rafindadi AA, Ozturk I. (2017). Dynamic Effects of Financial Development, Trade Openness and Economic Growth on Energy Consumption: Evidence from South Africa. International Journal of Energy Economics and Policy, 7(3), 74-85.

61. Rafiq S, Salim R, Nielsen I. (2016). Urbanization, openness, emissions, and energy intensity: a study of increasingly urbanized emerging economies. Energy Economics, 56, 20-8.

62. Rajbhandari A, Zhang F. (2017). Does Energy Efficiency Promote economic Growth?: Evidence from a Multi-Country and Multi-Sector Panel Data Set. World Bank Policy Research Working Paper No. 8077.DOI: https://ssrn.com/abstract=2985502

63. Rajneesh (2018). Do Trade Openness, Structure of the Economy and FDI Affect Energy Intensity in India? A Case for Including Energy Intensity as a Policy Parameter. The Indian Economic Journal, 65,1-4.

64. Rashid A, Yousaf N. (2015). Linkage of financial development with electricity growth, nexus of India and Pakistan. Euro Economica, 34(2), 151-60.

65. Sbia R, Shahbaz M, Hamdi HA. (2014). Contribution of foreign direct investment, clean energy, trade openness, carbon emissions and economic growth to energy demand in UAE. Economic Modelling, 36,191-7.

66. Sadorsky P. (2010). The impact of financial development on energy consumption in emerging economies. Energy Policy,38, 2528-35. 
67. Sadorsky P. (2011). Financial development and energy consumption in Central and Eastern Europe frontier economies. Energy Policy, 39, 999-1006.

68. Saudi MHM, Sinaga O, Roespinoedji D, Ghani EK. (2019). The Impact of Technological Innovation on Energy Intensity: Evidence from Indonesia. International Journal of Energy Economics and Policy, 9(3), 11-17.

69. Shahbaz M. (2015). Electricity consumption, financial development and economic growth nexus in Pakistan: a visit. Bulletin of Energy Economics, 3(2), 48-65.

70. Shahbaz M, Mallick H, Mahalick MK, Sadorsky P. (2016). The role of globalization on the recent evolution of energy demand in India: implications for sustainable development. Energy Economics, 55, 52-68.

71. Shahbaz M, Nasreen S, Ling CH, Sbia R. (2014). Causality between trade openness and energy consumption: what causes what in high, middle and low-income countries? Energy Policy 70,126-43.

72. Shahbaz M, Hye QMA, Tiwari AK, Leitão NC, (2013). Economic growth, energy consumption, financial development, international trade and $\mathrm{CO} 2$ emissions in Indonesia. Renewable and Sustainable Energy Review 25, 109-121.

73. Shahbaz M, Khan S, Tahir MI, (2013). The dynamic links between energy consumption, economic growth, financial development and trade in China: fresh evidence from multivariate framework analysis. Energy Economics, 40, 8-21.

74. Siddique HAB, Majeed MT, (2015). Energy Consumption, Economic Growth, Trade and Financial Development Nexus in South Asia. Pakistan Journal of Commerce and Social Sciences, 9 (2), 658-682.

75. Sims CA. (1986). Are forecasting models usable for policy analysis? Quart Rev Fed Reserv Bank Minneapolis, 10(1), 2-16.

76. Sohag K, Begum RA, Abdullah SMS, Jaafar M. (2015). Dynamics of energy use, technological innovation, economic growth and trade openness in Malaysia. Energy, 90(2), 1497-507.

77. Tamazian A, Chousa JP. Vadlamannati KC. (2009). Does higher economic and financial development lead to enviromental degradation: Evidence from BRIC countries. Energy Policy 37, 246-253.

78. Tan ZF, Zhang JL. (2010). Research on the dynamic relationship between energy efficiency and its influencing factors in China. Chinese Journal of Population Resources and Environment, 20(4), 43-9.

79. Tang CF, Tan EC. (2013). Exploring the nexus of electricity consumption, economic growth, energy prices and technology innovation in Malaysia. Applied Energy, 104, 297305.

80. Wan J, Baylis K, Mulder P. (2015). Trade-facilitated technology spillovers in energy productivity convergence processes across EU countries. Energy Economics, 48, 253-64.

81. Wei WX, Chen D, Hu D. (2016). Study on the evolvement of technology development and energy efficiency. Sustainability, 8(5), 457.

82. Wing, IS (2008). Explaining the declining energy intensity of the US economy. Resource and Energy Economics, 30(1), 21-49.

83. Zhang, Y. J. (2011) The Impact of Financial Development on Carbon Emissions: An Empirical Analysis in China. Energy Policy 39:4, 2197-2203. 
Table-a.1: Summary Statistics

\begin{tabular}{|l|c|c|c|c|c|}
\hline & $E e f_{t}$ & Fdev $_{t}$ & Topen $_{t}$ & Tinnov $_{t}$ & Egr $_{t}$ \\
\hline Mean & 5.220 & 0.296 & 33.40 & 937.4 & 876.5 \\
\hline Median & 5.392 & 0.212 & 33.33 & 922.0 & 825.8 \\
\hline Maximum & 5.856 & 1.000 & 38.90 & 1738.0 & 1158.5 \\
\hline Minimum & 4.277 & 0.000 & 25.30 & 476.0 & 653.7 \\
\hline Std. Dev. & 0.446 & 0.266 & 3.433 & 352.8 & 135.9 \\
\hline Skewness & -0.661 & 1.304 & -0.593 & 0.399 & 0.305 \\
\hline Kurtosis & 2.305 & 3.720 & 2.988 & 2.272 & 2.067 \\
\hline Jarque-Bera & 3.068 & 10.077 & 1.935 & 1.604 & 1.710 \\
\hline Probability & 0.215 & 0.006 & 0.379 & 0.448 & 0.425 \\
\hline Observations & 33 & 33 & 33 & 33 & 33 \\
\hline
\end{tabular}

Note: The results are estimating before taking logarithm.

Table-a.2: PCA for Financial Development Index

\begin{tabular}{|c|c|c|c|c|c|}
\hline Component & Eigen value & Difference & Proportion & \multicolumn{2}{c|}{ Cumulative } \\
\hline PC1 & 2.685 & 1.145 & 0.637 & 0.637 \\
\hline PC2 & 1.539 & 0.982 & 0.258 & 0.895 \\
\hline PC3 & 0.557 & 0.349 & 0.081 & 0.976 \\
\hline PC4 & 0.208 & 0.198 & 0.023 & 0.999 \\
\hline PC5 & 0.009 & \multicolumn{5}{|c|}{0.001} & \multicolumn{2}{c|}{ P } & 0.00 \\
\hline \multicolumn{7}{|c|}{ Principal components (eigenvectors) } \\
\hline Variable & PC1 & PC2 & PC3 & PC4 & PC5 \\
\hline Eef & -0.538 & 0.297 & $-0.373 \mathrm{~A}$ & 0.268 & 0.645 \\
\hline Egr $_{t}$ & 0.591 & -0.069 & 0.281 & -0.136 & 0.740 \\
\hline Fdev $_{t}$ & 0.118 & 0.750 & -0.155 & -0.626 & -0.080 \\
\hline Topen $_{t}$ & -0.422 & 0.254 & 0.869 & 0.006 & 0.032 \\
\hline Tinnov $_{t}$ & 0.414 & 0.528 & 0.048 & 0.720 & -0.167 \\
\hline
\end{tabular}

Table-a.3: VAR Residuals Correlation matrix

\begin{tabular}{|l|l|l|l|l|l|}
\hline Variables & Eef & Fdev $_{t}$ & Topen $_{t}$ & Tinnov $_{t}$ & Egr $_{t}$ \\
\hline Eef $_{t}$ & 1.000 & & & & \\
\hline Fdev $_{t}$ & 0.897 & 1.000 & & & \\
\hline Topen $_{t}$ & -0.216 & 0.034 & 1.000 & & \\
\hline Tinnov $_{t}$ & 0.348 & 0.568 & 0.691 & 1.000 & \\
\hline Egr $_{t}$ & -0.381 & 0.589 & 0.090 & 0.297 & 1.000 \\
\hline
\end{tabular}

Note: Lower triangular entries are presented in Table. 
Figures

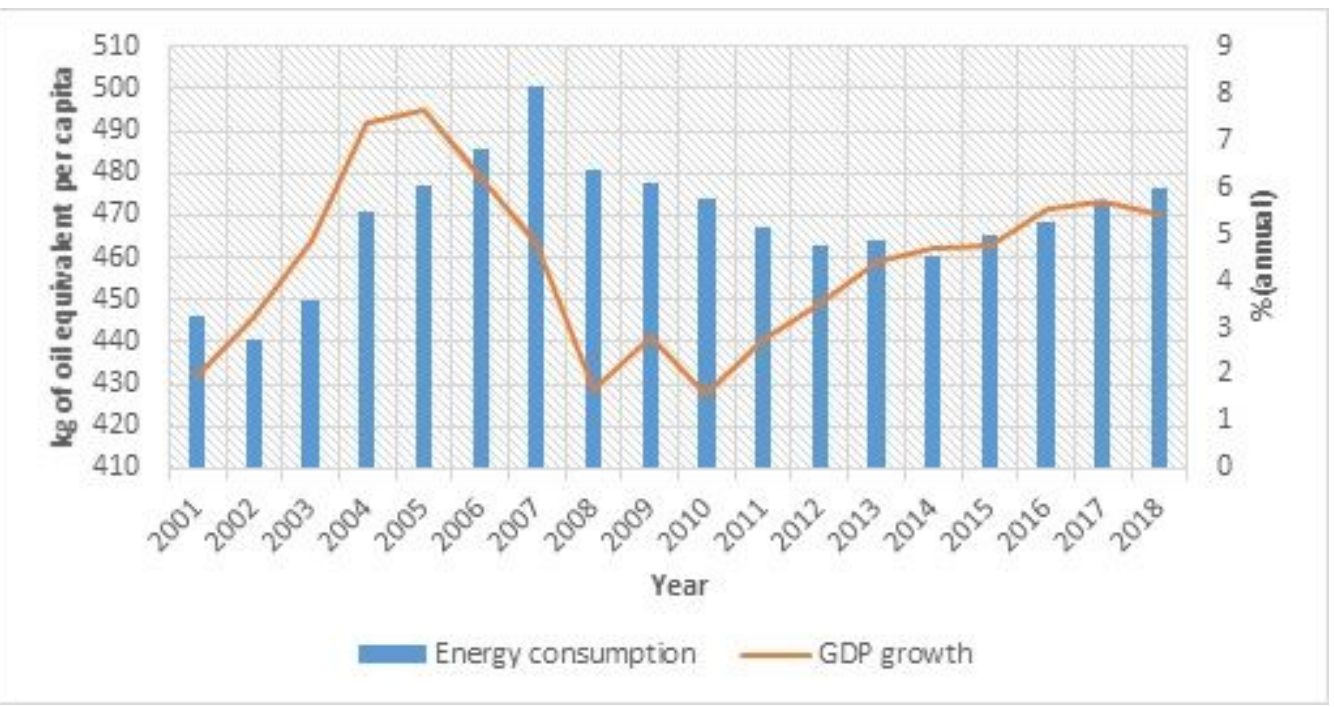

\section{Figure 1}

Trends in Energy Consumption and Economic Growth. Sources: WDI, World Bank

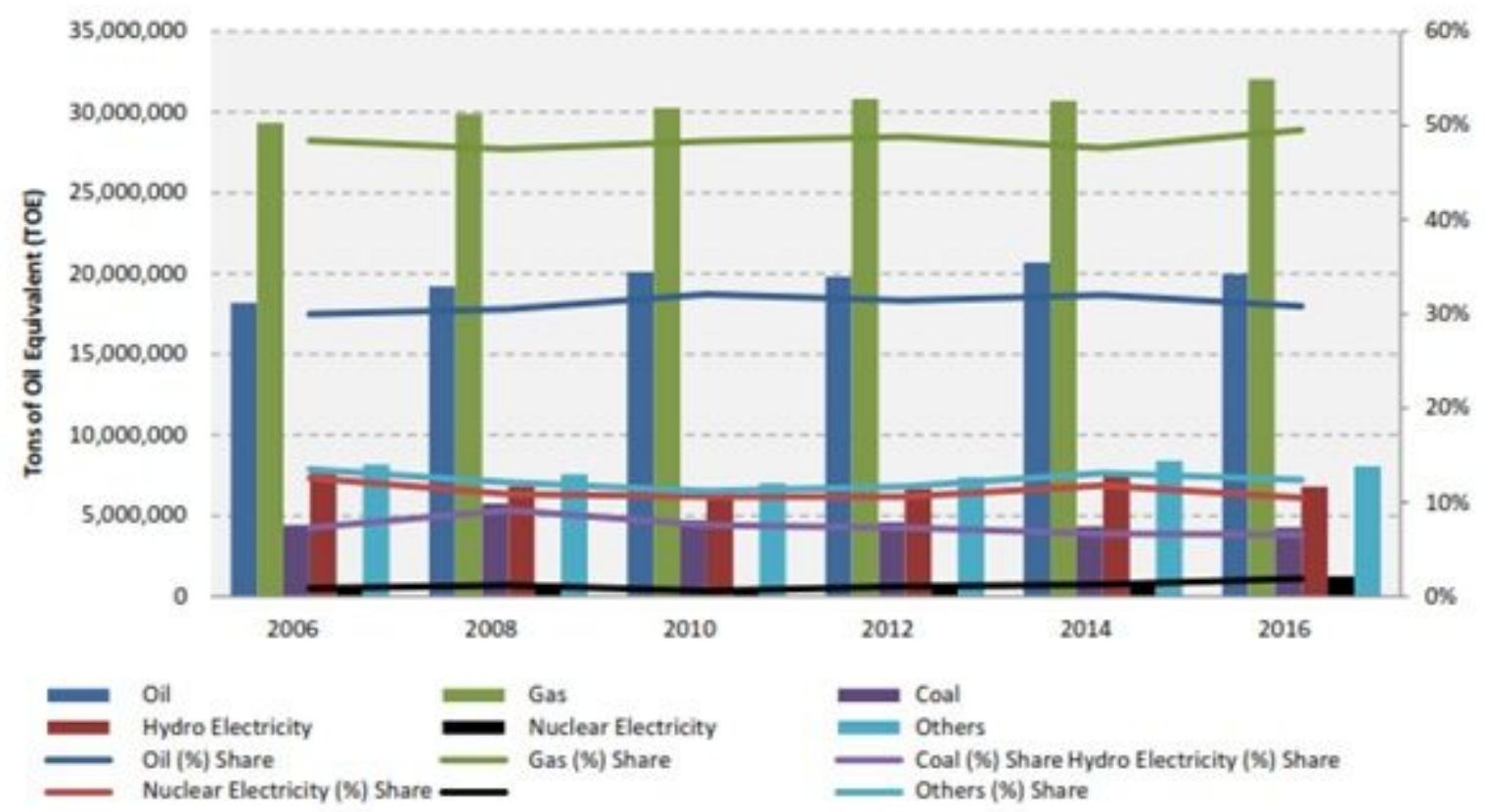

Figure 2

Share of Energy Sources in Primary Energy Supply. Source: Hydrocarbon Development Institute of Pakistan 

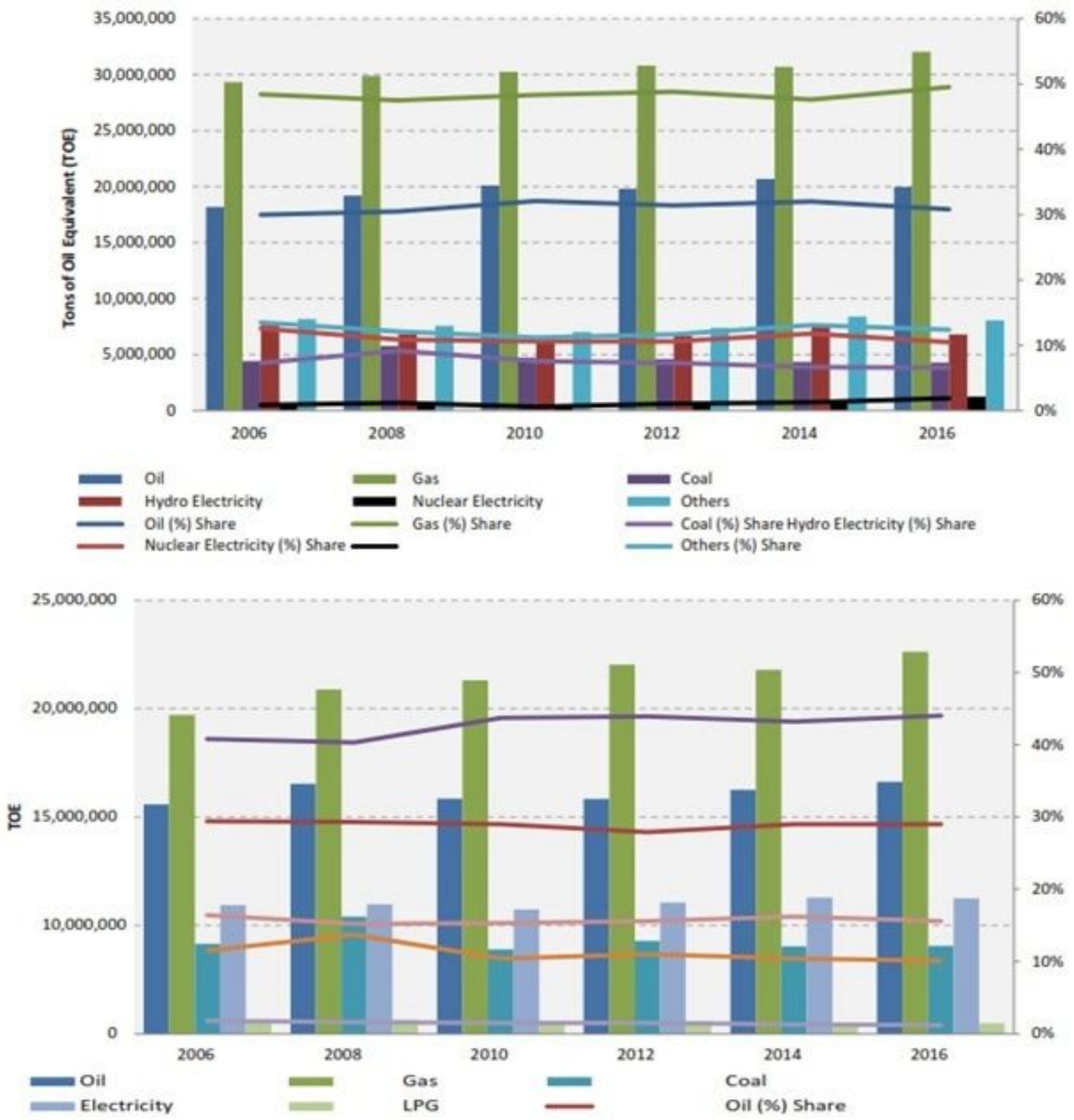

Figure 3

Contribution of Energy Sources in Final Energy Consumption. Source: Hydrocarbon Development Institute of Pakistan 


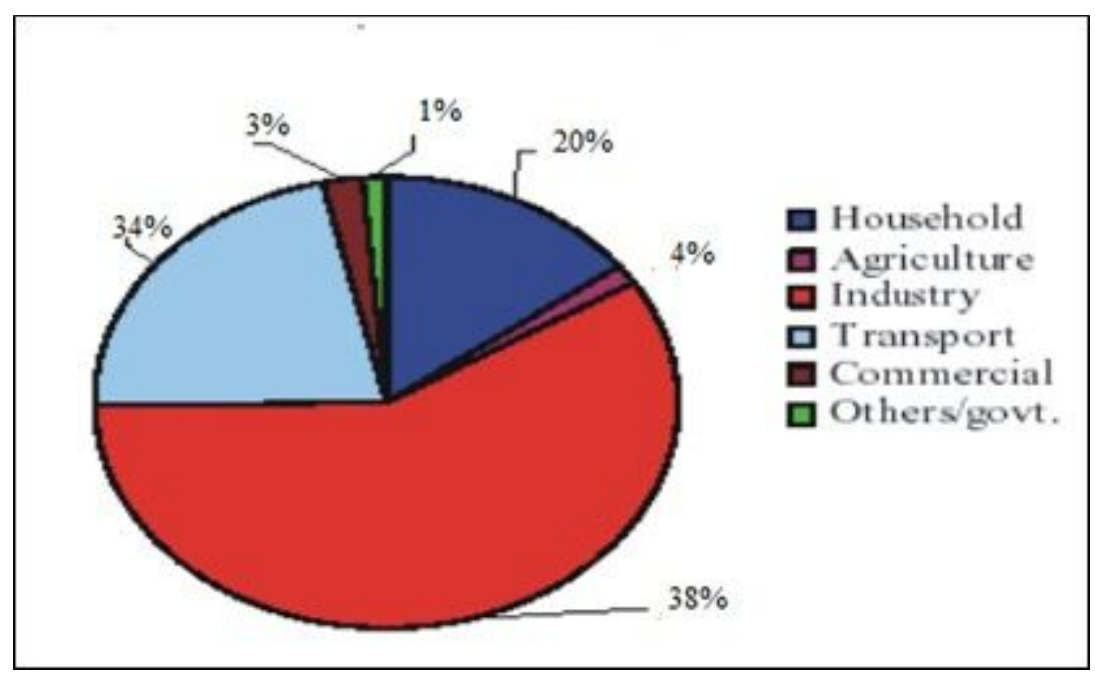

\section{Figure 4}

Distribution of Energy by Sector. State Bank of Pakistan, Quarterly Report for the Year 2017.

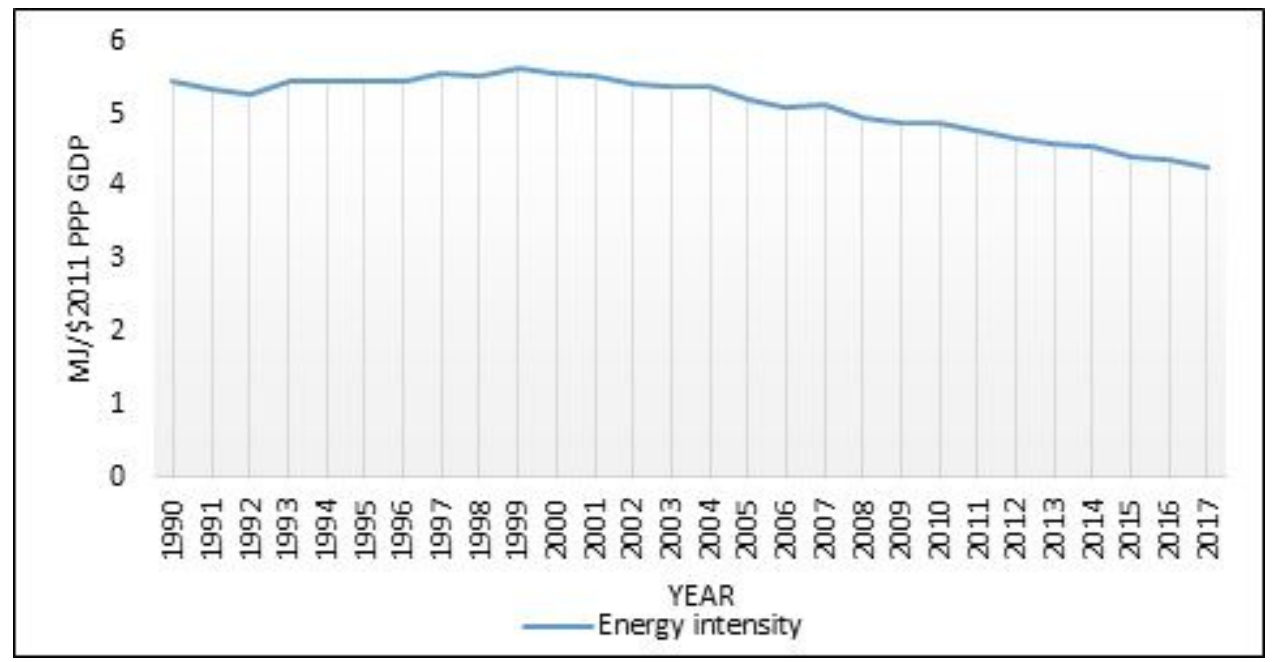

Figure 5

Trends in Energy Efficiency. Source: WDI, World Bank 


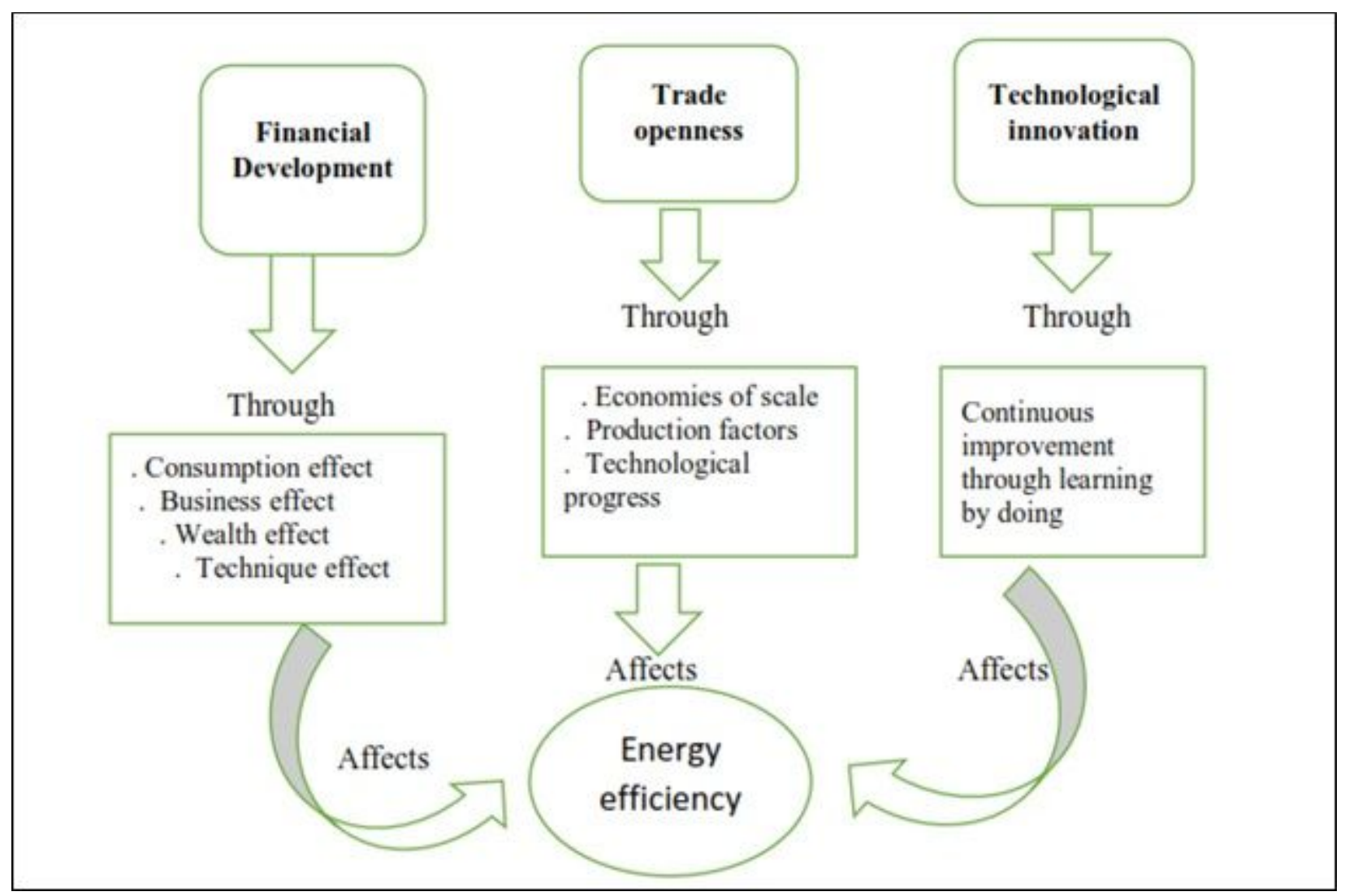

Figure 6

Interconnection between energy efficiency, financial development, trade openness and technological innovation

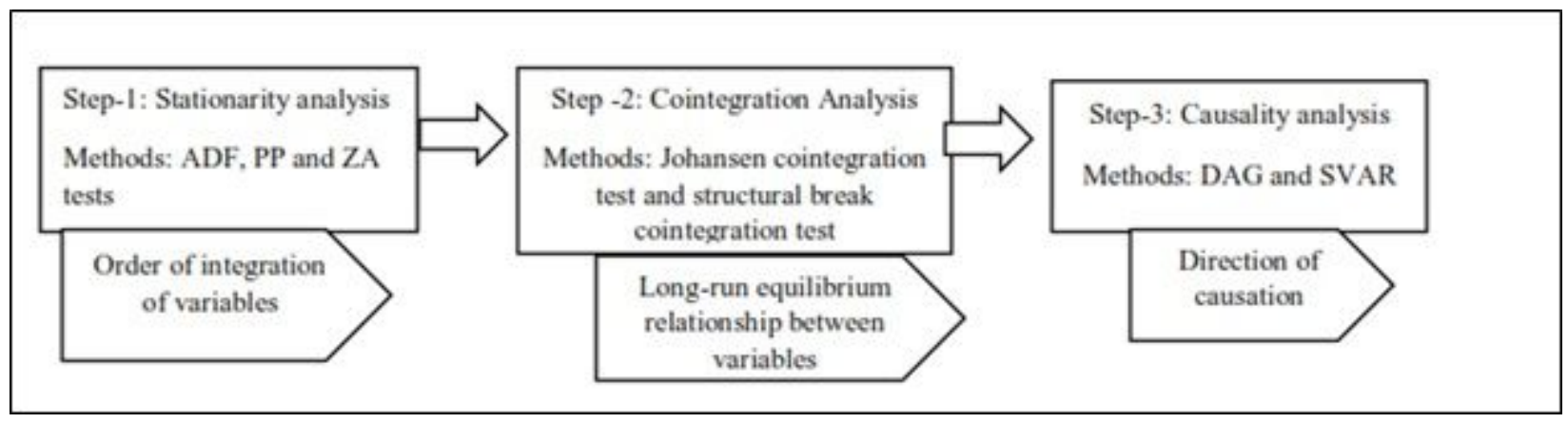

\section{Figure 7}

Overview of estimation methods 


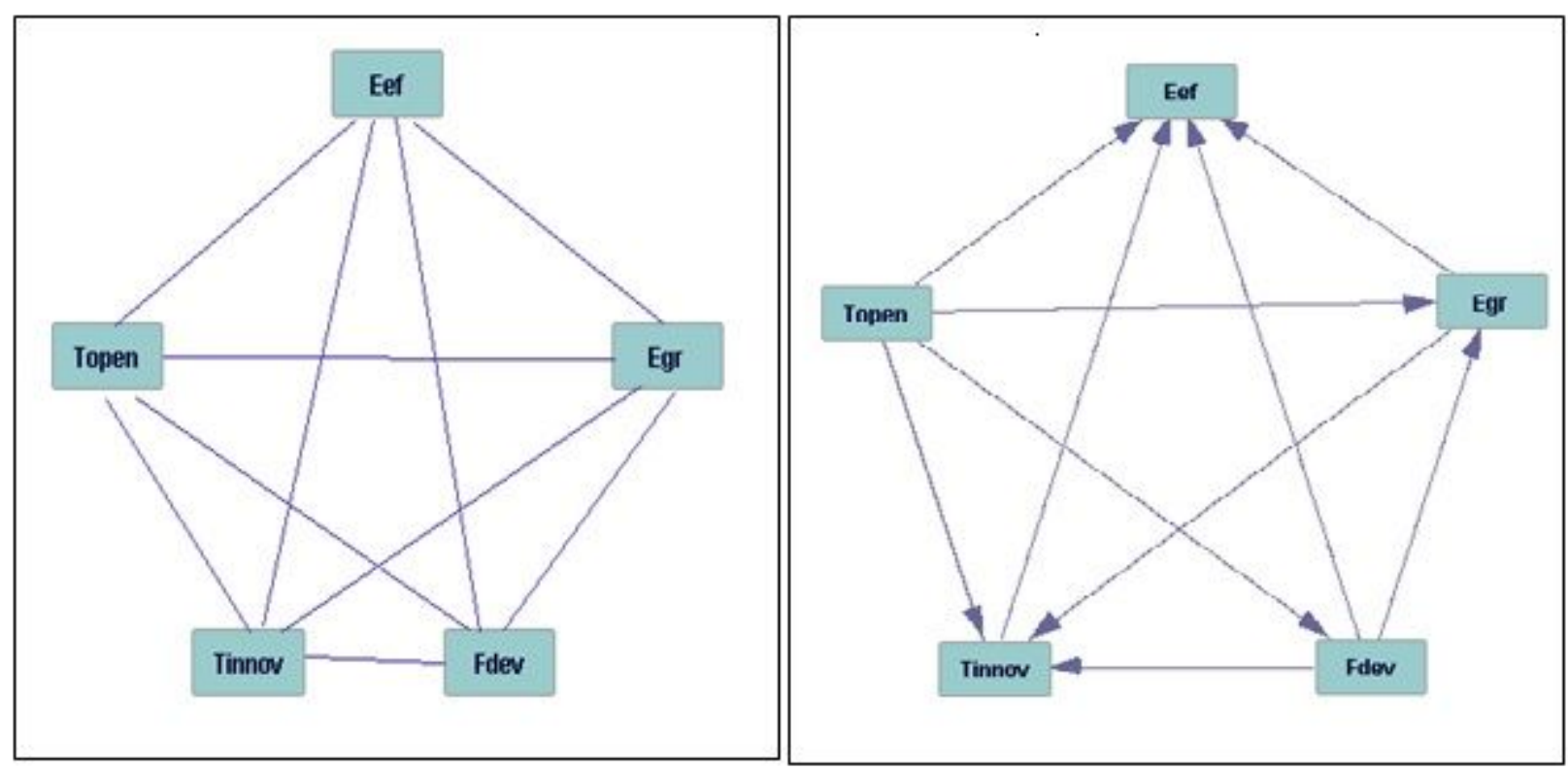

Figure 8

(a): Complete undirected graph (b): Directed acyclic graph 